\title{
Karstic spring wetlands of the Persepolis Basin, southwest Iran: unique sediment archives of Holocene environmental change and human impacts
}

\author{
Morteza Djamali, Sébastien Gondet, Javad Ashjari, Cyril Aubert, Elodie Brisset, Julien Longerey, \\ Nick Marriner, Marjan Mashkour, Naomi F. Miller, Abdolmajid Naderi-Beni, Majid Pourkerman, \\ Elnaz Rashidian, Jean-Baptiste Rigot, Sonia Shidrang, Alain Thiéry, and Emmanuel Gandouin
}

\begin{abstract}
Palustrine carbonates are frequently found with active and dried karstic springs in the foothills of the mountains bordering the Persepolis Basin, southwest Iran. A combination of geological conditions favours their formation, including $(i)$ the presence of karstic limestone aquifers in the limbs of anticlines cut through by fault systems; (ii) very gentle slopes from the spring resurgence point towards the centre of the alluvial plain, creating a flat waterlogged area; and (iii) a semiarid climate with marked precipitation seasonality or significant fluctuations in water discharge and wetland water table. We suggest the term "anastomosing wetlands" or "anastomosing palustrine environments" to denote the studied karstic spring-fed carbonate wetlands, because of similarities with anastomosing river systems in aerial view. The common presence of extended anastomosing wetland carbonates in the Persepolis Basin and adjacent basins in the central and southern Zagros suggests that they can play an important role in the geological records of collision-related basin-and-range settings dominated by karstic limestones. Karstic spring wetlands are a main source of fresh water hosting a rich biodiversity, which attracts human communities, whose impact is visible in the archaeological material imbedded in the wetland stratigraphy. Fresh water availability, through these spring wetlands, partly explains why the semiarid Persepolis region was selected by successive civilizations, from Elamites to Persians until early Islamic entities, to establish regional centres throughout the period from the third millennium B.C. to the first millennium A.D. Only a few of these ecosystems have survived the intensive human activities of recent decades.

Résumé : Des carbonates palustres sont fréquemment associés à des sources karstiques actives et asséchées dans le contrefort des montagnes bordant le bassin de Persépolis, dans le sud-ouest de l'Iran. Une combinaison de conditions géologiques favorise leur formation, à savoir : $i$ ) la présence d'aquifères de calcaires karstiques dans les flans d'anticlinaux découpés par des systèmes de failles, ii) les pentes très douces des points de résurgence de sources vers le centre de la plaine alluviale, créant une zone plane saturée et iii) un climat semi-aride caractérisé par une saisonnalité marquée des précipitations ou d'importantes fluctuations de l'écoulement de l'eau et de la nappe phréatique dans les zones humides. Nous proposons le terme "zones humides anastomosées » ou « milieux palustres anastomosés » pour désigner les zones humides à carbonates karstiques alimentées par des sources en raison de similitudes qu'elles présentent en vue aérienne avec des réseaux hydrographiques anastomosés. La présence répandue de carbonates dans les zones humides anastomosées du bassin de Persépolis et des bassins voisins des parties centrales et sud des monts Zagros indiquerait qu'ils peuvent jouer un rôle important dans les profils géologiques des milieux de bassins et montagnes. Ces milieux sont associés à des collisions tectoniques dans lesquels prédominent des calcaires karstiques. Les zones humides karstiques alimentées par des sources constituent une source d'eau douce majeure abritant une grande diversité
\end{abstract}

Received 13 March 2018. Accepted 16 June 2018.

Paper handled by Editor Ali Polat.

M. Djamali, C. Aubert, A. Thiéry, and E. Gandouin. Institut Méditerranéen de Biodiversité et d'Ecologie, Aix Marseille Univ, Univ Avignon, Centre National de la Recherche Scientifique, Institut de Recherche pour le Développement, Europôle de l'Arbois, 13545 Aix-en-Provence, France.

S. Gondet. Université de Lyon, Archéorient Maison de l’Orient et de la Méditerranée, Unité Mixte de Recherche CNRS 5133/Université de Lyon II, 7, rue Raulin, F-69365 Lyon cedex 07, France.

J. Ashjari. Abanrood Consulting Company, 311 Jamalzadeh Street, Tehran, Iran.

E. Brisset. Institut Català de Paleoecologia Humana i Evolució Social, Zona Educacional 4, Campus Sescelades Universitat Rovira i Virgili (Edifici W3), 43007 Tarragona, Spain; Àrea de Prehistòria, Universitat Rovira i Virgili, Avinguda de Catalunya 35, 43002 Tarragona, Spain.

J. Longerey. Aix-Marseille Univ, UMS3470 Pythéas, Marseille, France.

N. Marriner. Laboratoire Chrono-Environnement Unité Mixte de Recherche CNRS 6249/Université de Franche-Comté, Unité de Formation et de Recherche ST, 16 route de Gray, 25030 Besançon, France.

M. Mashkour. Archéozoologie, Archéobotanique: sociétés, pratiques et environnements, Unité Mixte de Recherche Centre National de la Recherche Scientifique 7209, Muséum National d'Histoire Naturelle, case postale 56, 55 rue Buffon, 75005 Paris, France.

N.F. Miller. Near East Section, University of Pennsylvania Museum, 3260 South Street, Philadelphia, PA 19104, USA.

A. Naderi-Beni and M. Pourkerman. Iranian National Institute for Oceanography and Atmospheric Sciences, Tehran, Iran.

E. Rashidian. Institute of Archaeology, Department of the Archaeology of the Ancient Near East, Goethe University Frankfurt, Norbert-Wollheim-Platz 1, D-60629 Frankfurt am Main, Germany.

J.-B. Rigot. Unité Mixte de Recherche 6173 CItés, TERritoires, Environnement et Sociétés (Centre National de la Recherche Scientifique et Université de Tours) - 33 allée Ferdinand-de-Lesseps BP 60449 - 37204 Tours Cedex 3, France.

S. Shidrang. Saeedi Institute for Advanced Studies, Kashan University, Qotb-e Ravandi Blvd, 8731753153, Kashan, Isfahan, Iran.

Corresponding author: Morteza Djamali (email: morteza.djamali@imbe.fr). 
biologique qui attire les collectivités humaines, dont l'impact est visible dans le matériel archéologique présent dans la stratigraphie des zones humides. La disponibilité d'eau douce qu'offrent ces zones humides alimentées par des sources explique en partie pourquoi la région semi-aride de Persépolis a été retenue par des civilisations successives, des Élamites aux Perses jusqu'aux premières entités islamiques, pour y établir des centres régionaux durant toute la période allant du $3^{\mathrm{e}}$ millénaire avant notre ère au $1^{\text {er }}$ millénaire de notre ère. Seuls quelques-uns de ces écosystèmes ont survécu à l'intense activité humaine des récentes décennies. [Traduit par la Rédaction]

\section{Introduction}

Palustrine carbonates are continental carbonates deposited in marginal shallow lake environments or wetland systems, later modified by subaerial exposure and pedogenic processes (Alonso-Zarza 2003; Alonso-Zarza and Wright 2009a). They belong to a spectrum of nonmarine carbonates including lacustrine carbonates, seasonal wetland carbonates, riparian and discharge carbonates, travertines and tufas, pedogenic and groundwater calcretes, and speleothems (Alonso-Zarza and Wright 2009a; Tanner 2010). Palustrine carbonates have been documented frequently in the post-Silurian formations of many continental basins (Freytet and Plaziat 1982; Platt and Wright 1992; Djamali et al. 2006; Khalaf and Gaber 2008) and are thus an important part of the geological record (Alonso-Zarza 2003; Alonso-Zarza and Tanner 2006; Wright and Platt 1995). Their presence is especially well documented in the Tertiary formations of the Iberian Peninsula (see references in Alonso-Zarza 2003). Palustrine carbonates can be recognized by a series of morphological features (Alonso-Zarza 2003; Alonso-Zarza and Wright 2009; Freytet 1973; Freytet and Verrecchia 2002). Most of these features have developed in a matrix of carbonate mud (micrite or microsparite) deposited in a lacustrine (Freytet 1984) or palustrine (wetland) environment (Plaziat 1984). Alonso-Zarza and Wright (2009) categorize these features into six common distinctive sedimentary facies: (i) mottled limestones ("marmorised" sensu Freytet 1973); (ii) nodular limestones; (iii) limestones with vertical root cavities and root traces; (iv) "pseudomicrokarst" limestones (Plaziat and Freytet 1978); ( $v$ ) peloidal, coated grain, and intraclastic limestones; and (vi) laminar calcretes (Alonso-Zarza and Wright 2009b).

Ancient palustrine carbonates have been attributed to several different depositional environments including shallow marginal lacustrine environments (Freytet 1984; Freytet and Plaziat 1982), seasonal continental wetlands (Wright and Platt 1995), peritidal environments (Platt and Wright 1992), ponds in river floodplains (Wright and Platt 1995), and distal alluvial environments (Bustillo and Alonso-Zarza 2007; Djamali et al. 2006). Palustrine-like deposits formed in spring-fed wetland complexes have also been documented (Ashley et al. 2004). However, modern analogues for these environments in which the palustrine carbonates are still being formed are very rarely documented (Alonso-Zarza and Wright 2009b). In this study, a particular kind of palustrine deposit, formed in karstic spring carbonate wetlands, is introduced.

Palustrine carbonate outcrops associated with former karstic springs were encountered at several localities around the Persepolis Basin in October 2012, while suitable archives for Quaternary paleoenvironmental studies were being sought. To our knowledge, no study has so far been devoted to the sedimentology of these deposits, and the only comprehensive geomorphological investigations in the basin have focused on the edaphic-sedimentary profiles formed around the Kur and Pulvar River systems in the more northwest and central parts of the basin (Kehl et al. 2005, 2009; Rigot 2010; De Schacht et al. 2012). Therefore, in light of the important scientific potential of these deposits (Alonso-Zarza 2003), we decided to locate and investigate these sediments, and the associated modern wetlands, throughout the basin in the southern Zagros Mountains.

Although several lakes have been investigated in an attempt to reconstruct the environmental history of these mountains and surrounding regions (e.g., Stevens et al. 2001; Djamali et al. 2008,
2009; Wasylikowa et al. 2008; Jones et al. 2015), the available records mostly reflect regional changes in climate and landscape. The paleoenvironmental records of these large lake systems do not speak to the local responses of ecosystems to global climate change and human activities, which are best investigated through the network of small wetland systems that lie in proximity to past human settlements. Lakes and peat bogs are not very common in the Zagros, but the karstic spring wetlands reported in this study can provide good evidence for human-climate-ecosystem interactions not only in the Persepolis Basin, but also in other sections of the Zagros Mountains (in Discussion).

The main objectives of this study are (i) to describe karstic spring-fed carbonate wetlands as modern analogues for ancient palustrine environments, (ii) to investigate the geological and hydrogeological context of these deposits, (iii) to understand the geometry and facies relationships of these sedimentary bodies, and (iv) to evaluate the scientific potential of these deposits for paleoenvironmental studies to investigate human-wetland interactions in the past. The Persepolis Basin of southwest Iran provides a perfect geoarchaeological context in which to address the last objective.

\section{Setting}

\section{Physical setting}

The study area is located in the southeastern part of the Zagros Mountains in the Fars Province of Iran. This mountain range stretches over $2000 \mathrm{~km}$ from the Strait of Hormuz in the southeast to the Iraqi-Syrian border in the northwest (Fig. 1: inset). Geologically, the southern Zagros falls within the Zagros folded belt (also called fold-thrust belt) in the tectono-sedimentary division of the Zagros (Mouthereau et al. 2012), in which northwest-southeasttrended anticlines are separated by synclines covered by thick alluvial sediments (see geological map in Fig. 1). Anticlines composed of Cretaceous karstic limestone formations belonging to the Bangestan and Khami groups form most of the geological outcrops bordering the north and west of the basin, whereas Tertiary marine limestones of the Asmari and Jahrum formations and gypsiferous red marls and marlstones of the Sachun and Razak formations dominate the southern ranges.

In this study, the Persepolis Basin is defined as the intermountain sedimentary basin corresponding to the Marvdasht plain and its two adjacent north and northwest subbasins, as delimited in Fig. 2. The topographic contour line of $1615 \mathrm{~m}$ approximately separates the alluvial plain of the Persepolis Basin from its bordering northwest-southeast-oriented mountain ranges, whereas in the associated subbasins, this elevation increases to about $1640 \mathrm{~m}$. The alluvial plain of the Persepolis Basin, with an average $0.06 \%$ gradient from northwest to southeast, is part of the Kur River catchment, which drains into the large playa lake system of Tashk and Bakhtegan (Kehl et al. 2009).

The Persepolis Basin is located in a Mediterranean continental climate (Djamali et al. 2011), with average annual precipitation of $<400 \mathrm{~mm} /$ year, a high continentality index (difference in mean temperatures in warmest and coldest months) of 26, and a maximum temperature of the warmest and minimum temperature of the coldest months being $37.5{ }^{\circ} \mathrm{C}$ and $-1.3^{\circ} \mathrm{C}$, respectively (see climatic data for Shiraz, Djamali et al. 2011). There is a marked precipitation seasonality, with a dry season lasting 7 to 8 months. 
Fig. 1. Geological map of the Persepolis Basin with the position of 13 karstic springs P0-P12 (P13 not shown) mentioned in the text (based on 1:1,000,000 Geological Map of southwest Iran, Geological and Exploration Division of IOOC 1969 and 1:100,000 Geological Map of Arsanjan, Yousefi et al. 2001). [Colour online.]

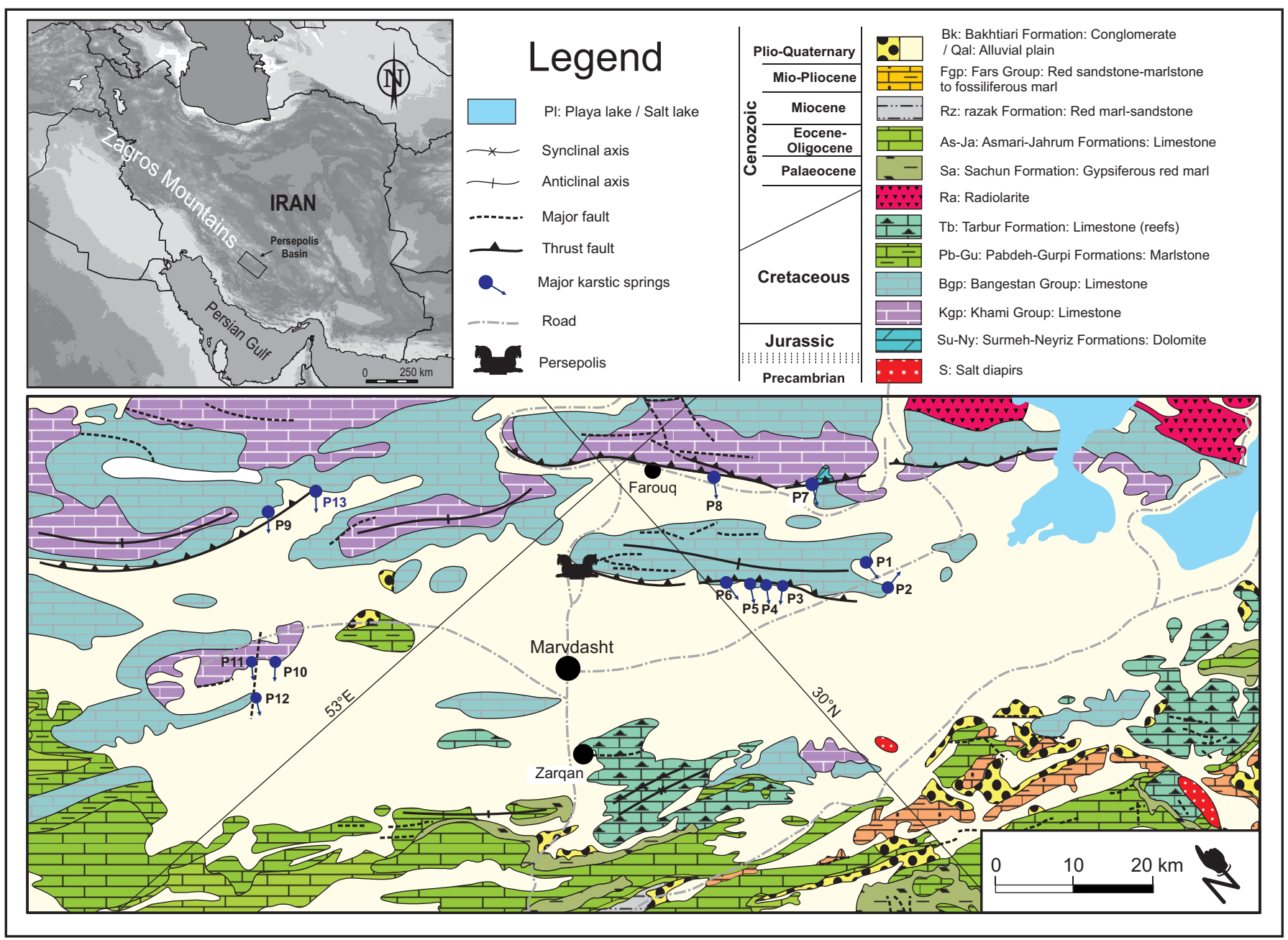

\section{Historical and archaeological context}

Human occupation in the Persepolis Basin goes back to the late Pleistocene (Rosenberg 1988; Tsuneki and Nishida 2007; Shidrang et al., in press). The discoveries of lithic artifacts in several caves and rock shelters in the Marvdasht plain range from Middle Palaeolithic to Epi-Palaeolithic localities (Rosenberg 1985, 1988, 2003; Scott and Marean 2009). On the basis of several excavations from the 1960s and absolute dating results obtained systematically during recent excavations, it can be documented that the basin has been inhabited by human communities almost continuously since the eighth millennium B.C. (e.g., Sumner 2003; Pollock et al. 2003; Mashkour et al. 2006; Komijani et al. in press). The Persepolis Basin is one of the major archaeological regions in Iran where one can observe the development of village life, to the formation of urban communities, through the complexification of chiefdoms and ruling dynasties. The emergence of the Elamites as a political regional power during the fourth millennium B.C., (Amiet 1996; Alizadeh 2006; Potts 1999) started the long tradition of ruling dynasties in the plain of Persepolis that lasted for almost 4000 years, until the fall of the Sasanian Empire (Daryaee 2013). This long-lasting record of ruling power also left an imprint on the landscape. The large number of archaeological sites and monuments in this region also explains the enthusiasm of archaeologists looking to better document the history of the region.
Several campaigns of archaeological excavations conducted by W. Sumner at Tall-e Malyan (Maliân) during the 1970s revealed the presence of a city in the northwestern part of the Persepolis Basin that corresponds to the city of Anshan known through texts as the highland capital of the Elamites (Sumner 1972, Reiner 1973, Vallat 1980; Abdi 2005). However, the most remarkable archaeological site of the Persepolis Basin is the World Heritage site of Persepolis, with its palace complex, dating to the Achaemenid Persian Empire (560-330 B.C.) (see bibliography in Mousavi 2012), situated on the northwestern end of the Mehr Anticline (i.e., the Kuh-e Rahmat mountain range; Fig. 2). Recent geophysical surveys have revealed the presence of complex irrigation networks developed during the rule of the Achaemenid Empire (Boucharlat et al. 2011; Gondet 2011; Boucharlat et al. 2011; De Schacht et al. 2012). The Persepolis Basin was the core region of two of the largest empires in the history of the ancient world: the Achaemenid and Sasanian Empires (560-330 B.C. and 224-650 A.D., respectively). During the Middle Ages and into modern times, the Persepolis Basin remained an important agricultural plain of Persia, as attested to by the numerous archaeological remains of dams and other water works developed and maintained to irrigate agricultural lands (e.g., Ibn Balkhi 1921; Kortum 1976; Hosseini-Fasae 1984). One of the important cultural and human components of this area is the presence of nomads (Barth, 1961; Beck, 1986). The archaeozoologi- 
Fig. 2. Shaded relief map of the Persepolis Basin with the position of 14 spring wetlands and deposits discussed in this article. The limits of the Persepolis Basin in this study are marked by the dashed line. [Colour online.]

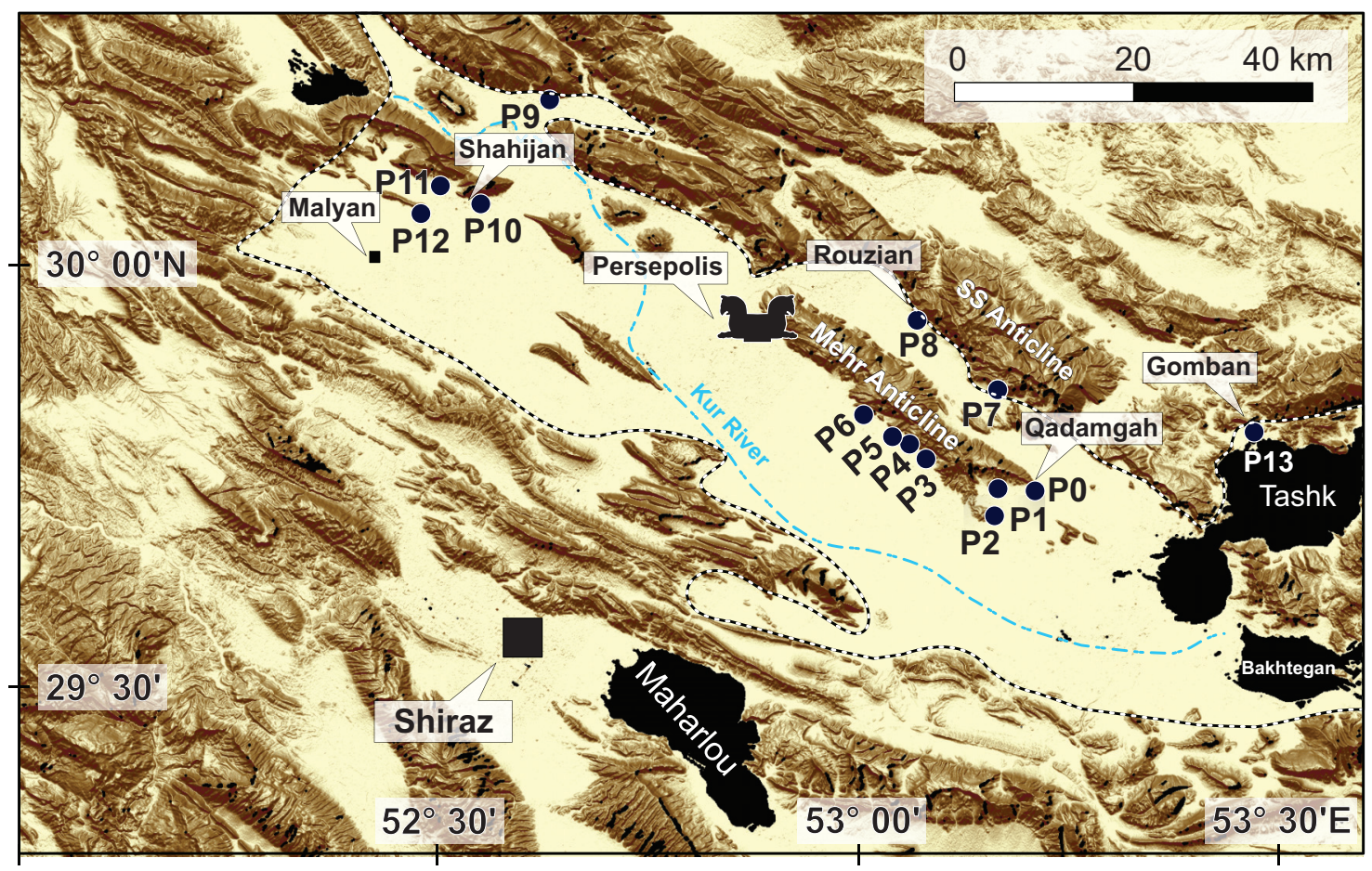

cal record from the early Neolithic shows the profound impact of pastoralism from the eighth millennium B.C. onwards, with the adoption of a nomadic lifestyle according to the availability of pasture lands during warm seasons (Sheikhi et al. 2011; Komijani et al. in press). It is probable that in this area, more nomadic pastoral communities lived alongside sedentary populations, with some periods characterized by decreasing sedentary occupations.

\section{Materials and methods}

Google Earth images from the last two decades were studied to detect seasonally and permanently waterlogged areas as well as possible subrecent spring palustrine deposits of the Persepolis Basin. Having detected 14 main springs and spring deposits, the spatial dimensions of the areas with anastomosing patterns (see later text) were delimited in Google Earth to calculate their approximate surface areas. The Google Earth KML file of the area was imported into ArcGIS and transformed into a series of georeferenced polygons in the WGS-1984 coordination system (using the conversion method). The wetland surface areas were calculated on the basis of their shapes, using the integrated geometry calculator method (Table 1). Landsat TM and OLI pseudo-colour $(752,763)$ were also used to help visualize the hydrological change in these wetland areas during the past two decades (Barsi et al. 2014; Fig. 3). The positions of the springs - spring wetlands mentioned earlier in the text were also plotted on geological maps to understand their formation (Fig. 1). They were then surveyed in the field for mapping, water sampling (if active), sedimentological description, and coring (October 2012). Thirteen water samples were taken from the spring resurgence points from the only active wetland with a high water discharge, the Rouzian wetland (P8 in Fig. 1 and Fig. 5) in two seasons (nine samples in October 2015 and four samples in June 2016). Water samples were then analyzed to quantify the concentration of major anions and cations (Fig. 6). A recently desiccated wetland called "Shahijan" (P10 in Fig. 1) was selected for additional field investigation and sediment sampling (Figs. 7, 8). Two sedimentary logs were drawn from different mi-
Table 1. Geographical position, slope gradient, and estimated surface areas of 14 karstic spring wetlands of the Persepolis Basin.

\begin{tabular}{lllll}
\hline Spring & Latitude & Longitude & Gradient & $\begin{array}{l}\text { Surface } \\
\text { area (ha) }\end{array}$ \\
\hline P0 & $29^{\circ} 44^{\prime} 0.31^{\prime \prime} \mathrm{N}$ & $53^{\circ} 12^{\prime} 42.72^{\prime \prime} \mathrm{E}$ & 0.16 & - \\
P1 & $29^{\circ} 42^{\prime} 51.24^{\prime \prime} \mathrm{N}$ & $53^{\circ} 9^{\prime} 17.94^{\prime \prime} \mathrm{E}$ & 0.56 & 126 \\
P2 & $29^{\circ} 43^{\prime} 50.95^{\prime \prime} \mathrm{N}$ & $53^{\circ} 9^{\prime} 52.91^{\prime \prime} \mathrm{E}$ & 0.18 & 517 \\
P3 & $29^{\circ} 46^{\prime} 10.53^{\prime \prime} \mathrm{N}$ & $53^{\circ} 4^{\prime} 15.00^{\prime \prime} \mathrm{E}$ & 0.44 & 218 \\
P4 & $29^{\circ} 47^{\prime} 11.28^{\prime \prime} \mathrm{N}$ & $53^{\circ} 3^{\prime} 20.33^{\prime \prime} \mathrm{E}$ & 0.28 & 351 \\
P5 & $29^{\circ} 47^{\prime} 53.39^{\prime \prime} \mathrm{N}$ & $53^{\circ} 2^{\prime} 14.93^{\prime \prime} \mathrm{E}$ & 0.35 & 99 \\
P6 & $29^{\circ} 49^{\prime} 6.92^{\prime \prime} \mathrm{N}$ & $53^{\circ} 0^{\prime} 38.67^{\prime \prime} \mathrm{E}$ & 0.25 & 610 \\
P7 & $29^{\circ} 51^{\prime} 3.45^{\prime \prime} \mathrm{N}$ & $53^{\circ} 8^{\prime} 8.43^{\prime \prime} \mathrm{E}$ & 0.37 & 207 \\
P8 & $29^{\circ} 54^{\prime} 48.74^{\prime \prime} \mathrm{N}$ & $53^{\circ} 5^{\prime} 26.41^{\prime \prime} \mathrm{E}$ & 0.1 & 789 \\
P9 & $30^{\circ} 12^{\prime} 12.29^{\prime \prime} \mathrm{N}$ & $52^{\circ} 37^{\prime} 42.55^{\prime \prime} \mathrm{E}$ & 0.16 & 527 \\
P10 & $30^{\circ} 4^{\prime} 54.38^{\prime \prime} \mathrm{N}$ & $52^{\circ} 31^{\prime} 24.51^{\prime \prime} \mathrm{E}$ & 0.78 & $2235^{*}$ \\
P11 & $30^{\circ} 5^{\prime} 29.31^{\prime \prime} \mathrm{N}$ & $52^{\circ} 30^{\prime} 10.39^{\prime \prime} \mathrm{E}$ & 0.21 & \\
P12 & $30^{\circ} 3^{\prime} 59.50^{\prime \prime} \mathrm{N}$ & $52^{\circ} 29^{\prime} 6.60^{\prime \prime} \mathrm{E}$ & 0.17 & \\
P13 & $29^{\circ} 48^{\prime} 10.09^{\prime \prime} \mathrm{N}$ & $53^{\circ} 28^{\prime} 34.68^{\prime \prime} \mathrm{E}$ & 0.23 & 279 \\
\hline
\end{tabular}

*Wetlands P10-12 were almost merged together and therefore their surface area was estimated together. Only the visible anastomosing surfaces of the wetlands were used to calculate the surface areas that represent their minimum extension.

crotopographical positions: one from an island-like white outcrop and the other from a channel-like, dark-coloured outcrop (Fig. 7; S1 and S2, respectively). These logs were drawn using exposed outcrops along the deep canals, dug to exploit the falling water table (Figs. 7, 8). Furthermore, two samples were taken from the westernmost part of the same canal (Figs. 7, 8A) for radiocarbon dating (Table 2). The samples were pretreated with $\mathrm{HCl}$ to remove carbonates and exclude any possible hard-water effect and contamination by old carbonates originating from the limestone formations. The only possibility for contamination remains the plant roots and rootlets penetrating into lower and older deposits from topsoil vegetation or aquatic plants living inside the wetland. Two thin sections were prepared from S1 using a special protocol adapted to soft and fragile sediments. Samples were first immerged in resin (Araldite 
Fig. 3. Landsat TM and OLI pseudo-colour images of the western Persepolis Basin in 1995 and 2016. Note that the spring wetlands P10-P12 (in dark blue in the left panel) are almost totally desiccated in 2016. [Colour online.]

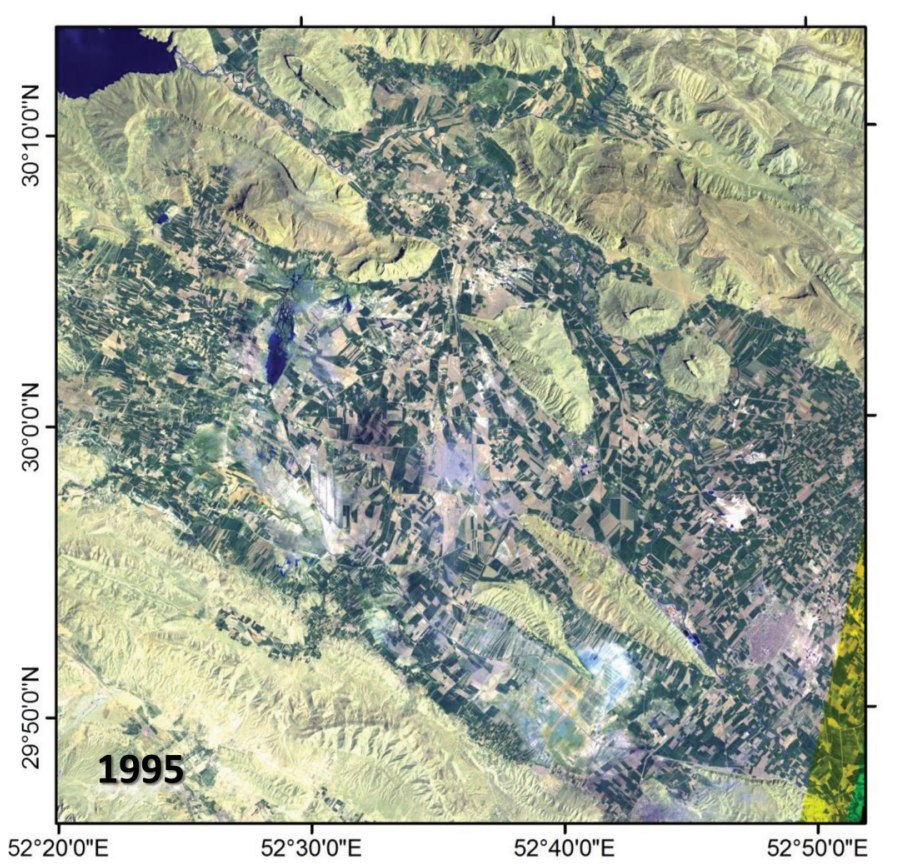

$52^{\circ} 20^{\prime} 0^{\prime \prime} \mathrm{5} \quad 52^{\circ} 30^{\prime} \mathrm{O}^{\prime \prime} \mathrm{E} \quad 52^{\circ} 40^{\prime} \mathrm{O}^{\prime \prime} \mathrm{E} \quad 0^{\prime} \mathrm{O}^{\prime \prime} \mathrm{E}$

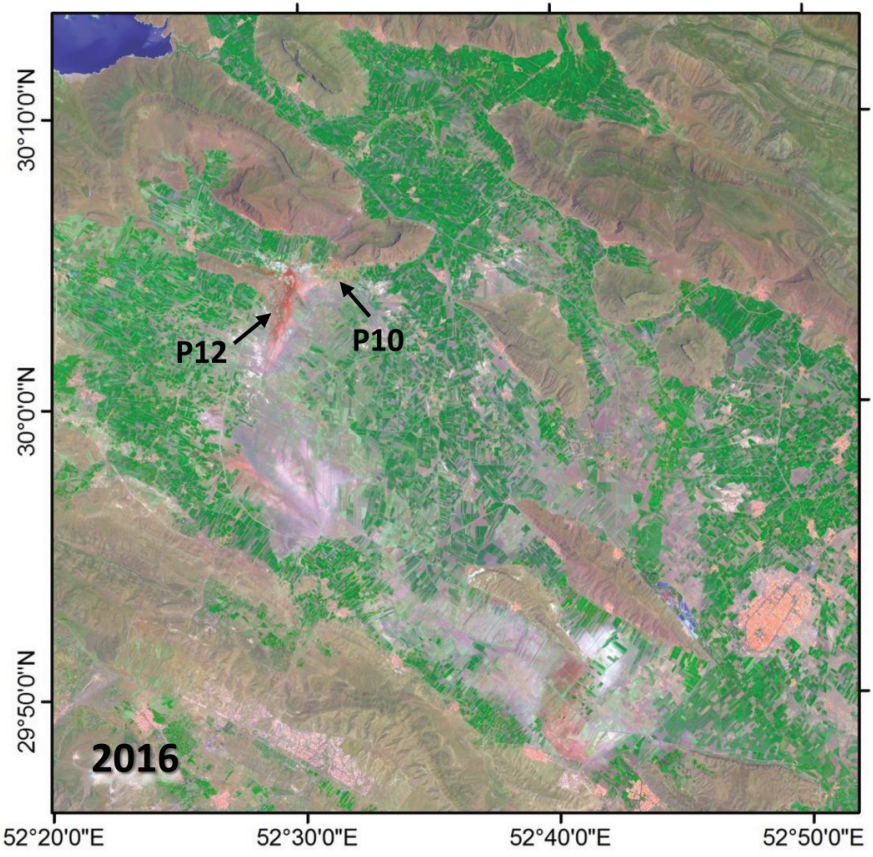

Kilometers

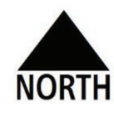

Fig. 4. (A and B) Two simple models to explain the formation of the karstic carbonate springs in the Persepolis Basin. In both cases, a karstic limestone formation is cut by a reverse or thrust fault. An impermeable marlstone formation then blocks water flow and creates a water conduit to the surface. The resurgence point can be located directly at the foot of the anticline (A) or some distance from it and within the alluvial plain forming "blue holes" (B). (C) Mechanism to explain the formation of small seasonal springs at the distal fringe of alluvial fans when the phreatic water table encounters the impermeable fine-grained or evaporitic sediments of the plain. Block diagrams represent simplified cross sections corresponding to the 4a, 4b, and 4c transects in Figs. 5A, 5B. [Colour online.]
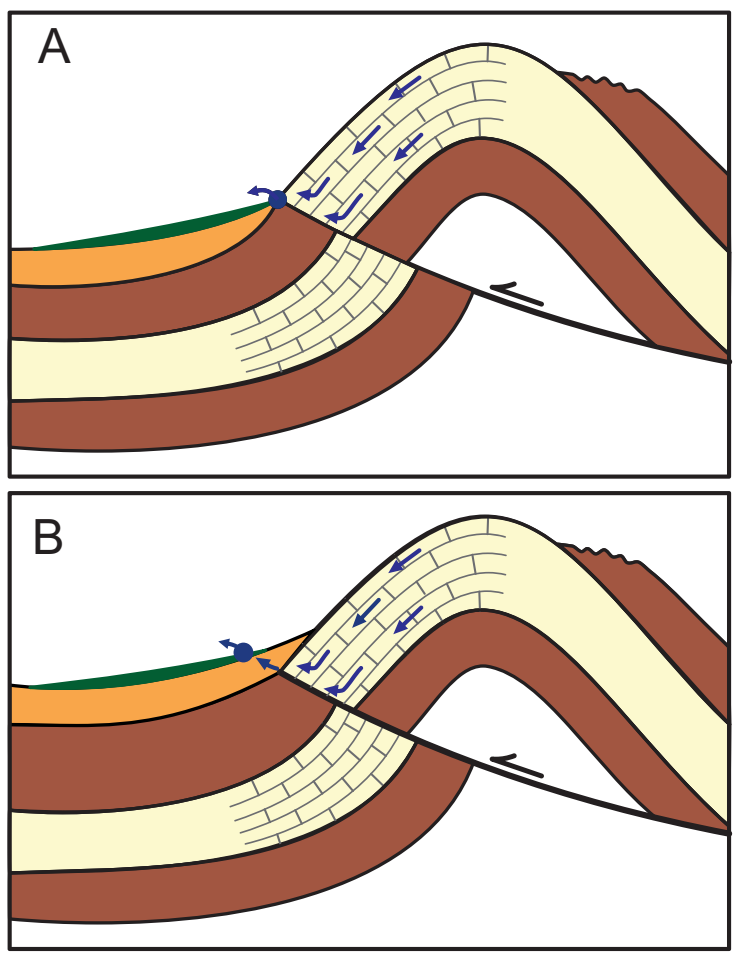

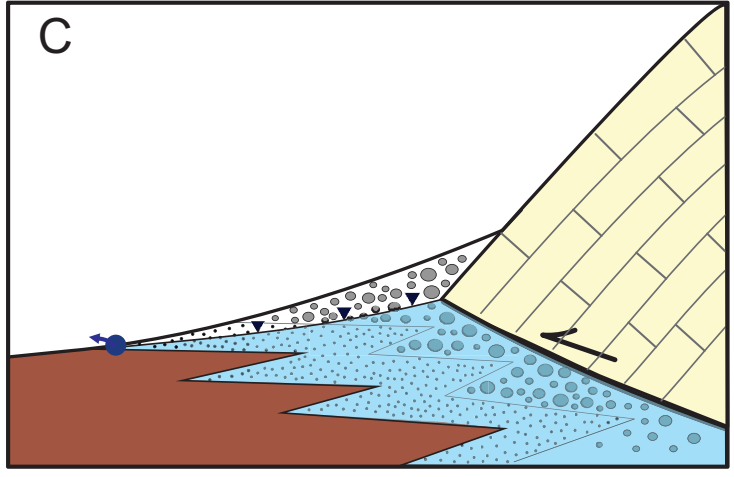

Karstic formation Alluvial deposits Impermeable marl/distal alluvial \& playa sediments

Wetland deposits

Colluvium

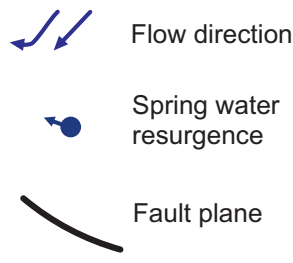

Coarse clastics 
Fig. 5. Satellite images of anastomosing carbonate wetlands in the Persepolis Basin. (A) Anastomosing wetlands south of the Mehr Anticline in the northern Persepolis Basin. (B and C) Rouzian (P8) wetland on the south of the Siah-Sydan Anticline (Fig. 1). The island-like features are areas of calcretic layers, whereas channel-like dark areas are areas of organic mud deposition and peat formation. Around the resurgence points of P8, a vast peatland has formed. P3-P6 have formed along a reverse fault in the south of the Mehr Anticline (see also Figs. 1, 2). These latter spring wetlands are nowadays completely desiccated. A is from Google Earth, CNES/Airbus 2017 (date of image 30 December 2016). B and C are from Google Earth, DigitalGlobe 2017 (date of image 1/07/2002). [Colour online.]
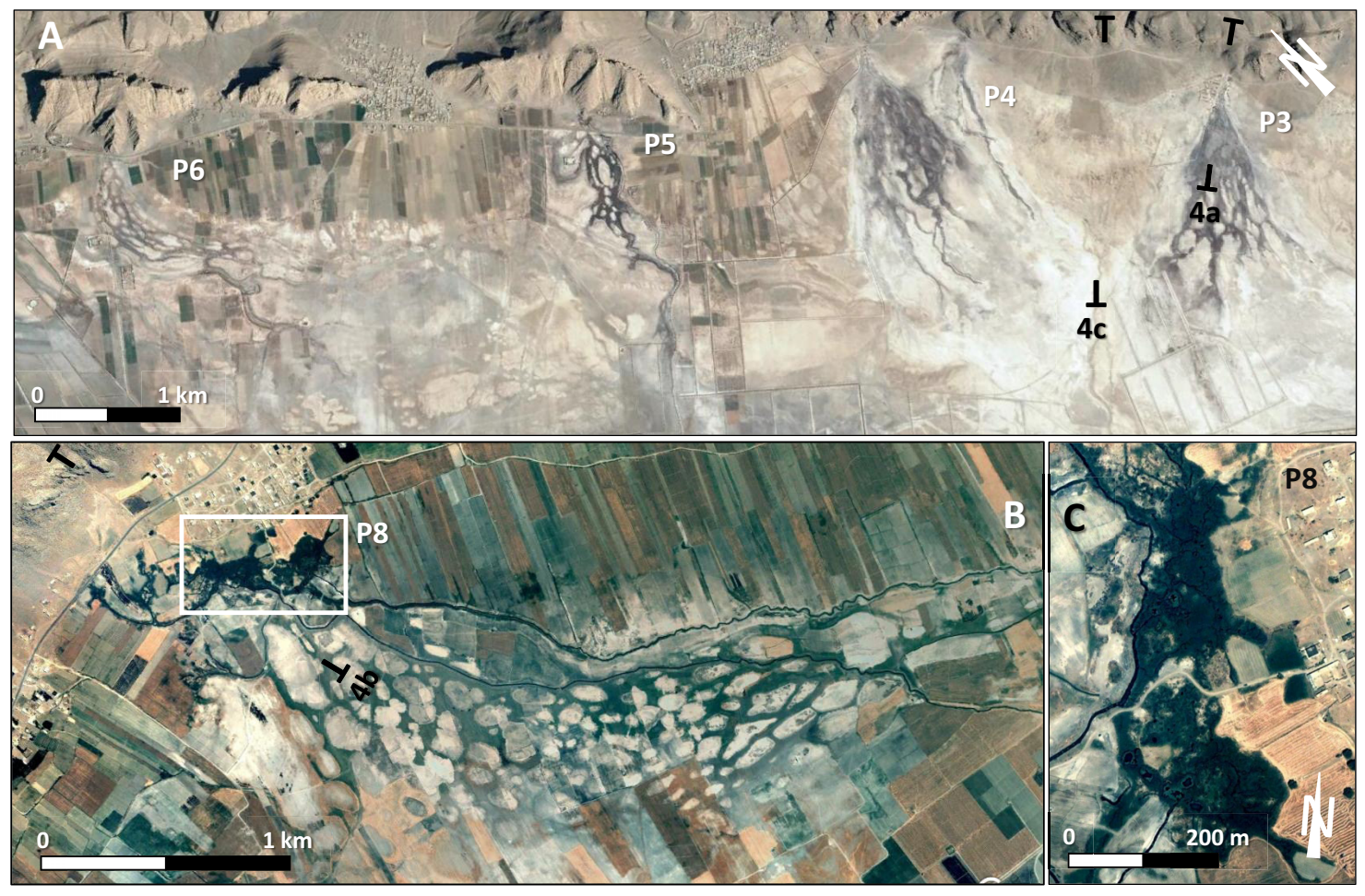

2020) under vacuum conditions and then polished with a fatty lubricant instead of water. The polished sections were then mounted on glass using another resin (Geofix). Next, the mounted sample was thinned using a circular saw equipped with a diamond blade. Finally, the sample was polished until it reached the critical thickness of $30 \mu \mathrm{m}$ before being covered by thermoplastic resin (Canada Basalm) and a coverslip.

\section{Results and interpretation}

\section{Hydrogeology of the karstic carbonate springs}

Figure 1 shows the position of the spring-fed palustrine deposits presented in this paper (P0-P12) superimposed on a geological map. Spring points 1-6 are associated with an intensely faulted northwest-southeast-oriented anticline called the Kuh-e Rahmat Anticline (also the Mehr Anticline), of which the westernmost end accommodates the archaeological site of Persepolis, the summer capital of the Achaemenid Empire, and spring wetlands P7-P8 are located in the south of the Siah-Sydan (or Siah-Seyyedan) Anticline to the north of Persepolis (SS Anticline in Fig. 2). Hydrogeologically, both anticlines are classified as being "NC" (no connectivity) with no hydraulic connectivity between their two limbs (see Ashjari and Raeisi $2006 a$ for the hydrogeological classification of anticlines). The spring (or palaeo-spring) resurgence points of P3-P6 are very precisely matched with the position of a long east-west-oriented reverse thrust fault cutting the Mehr Anticline in its southern flank (Fig. 1). These resurgence points seem to be aligned with the fault plane. A similar configuration is observed at springs P7 and P8, in which a reverse thrust fault has cut the southern limbs of the Siah-Sydan Anticline. However, in the latter case, the spring rise occurs a few hundred metres from the southern flanks of the anticline. The spring resurgence points P9 and P10 have also formed along reverse thrust faults cutting smaller anticlines in the northwest of the basin. The structural context of other springs is less straightforward and is a result of spring resurgence in a complex fractured zone (e.g., P12 and P13). Figure 4 presents the geological prerequisites for the formation of common types of karstic carbonate springs in the Persepolis Basin. In two more common cases (Figs. 4A, 4B), a limestone formation with a karstic aquifer encounters an impermeable marl, marlstone, or marly limestone displaced along the reverse thrust fault plane. The spring resurgence point may be located exactly on the fault strike, which is the situation with P3-P6 and P9-P10 (Fig. 4A), or some distance from the anticline limbs in the alluvial plain, which is observed clearly in P8 (Fig. 4B). In Fig. 4C, a third possible springforming mechanism is also shown, in which percolating run-off water through the colluvial sediments reaches an impermeable layer (marlstone geological formations or Quaternary fine-grained and (or) evaporitic sediments) and contributes to the formation of small springs. This last mechanism certainly has a less important role in contributing water to the wetlands and is of a more ephemeral and seasonal character. Examples of such small springs are found on the fan fringes, between resurgence points P4 and P5 (Fig. 5A).

During our field investigations (October 2012, October 2015, October and June 2016), only one active karstic spring wetland complex was found in the Persepolis region, located near the village of Rouzian (Figs. 1, 2: P8; Table 1). Most other springs seem to have dried up during the last two decades (see examples in Fig. 3).

The Piper diagram of samples taken in two seasons reveals a high amount of bicarbonate (Fig. 6) and shows that the water chemistry falls into the bicarbonate (B1) to bicarbonate-dominant (B2) water types according to the classification of Ashjari and Raeisi (2006b). Furthermore, the chemical composition of the 
Fig. 6. Piper diagram of anion and cation concentrations in water samples taken in two different seasons from a pond in the P8 spring wetland (Fig. 5B). Note that there are no significant seasonal variations in water chemistry. Orange triangles represent sediments taken in October 2015, and green rectangles represent samples taken in June 2016. Note that there is almost no shift in water chemistry between autumn and spring. [Colour online.]

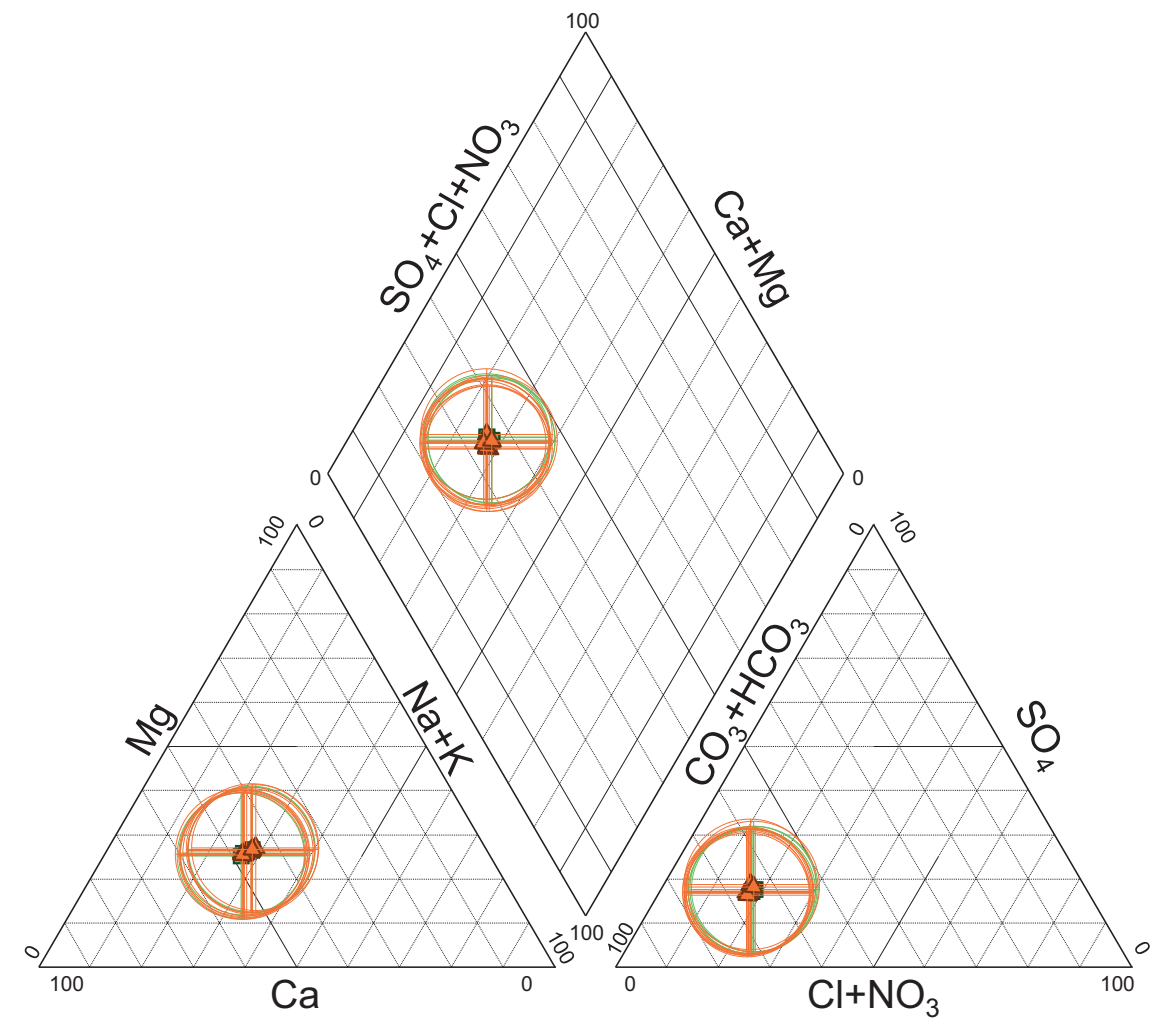

spring water does not change during the year (note the superposition of green and orange points in Fig. 6). These water types indicate that the water chemistry has been affected mostly by the karst formations and not by the neighbouring marly formations (Ashjari and Raeisi 2006b). On the basis of data presented in Ashjari and Raeisi (2006b), the bicarbonate concentrations are almost comparable to the springs sourcing from the Bangestan Group (Daryan-Gadvan-Fahlian formations) of the Early Cretaceous age.

\section{Geometry and sedimentary facies of the palustrine deposits}

Almost all the palustrine deposits shown in Fig. 2 display a downstream anastomosing pattern characterized by a network of light-coloured, island-like areas separated by dark-coloured channel areas (Figs. 5A, 5B). The island areas may be very large (e.g., up to $250 \mathrm{~m} \times 1200 \mathrm{~m}$ in P12) or very small ( $5 \mathrm{~m} \times 5 \mathrm{~m}$ in P8). Channel width can vary from a few metres to $>250 \mathrm{~m}$ (P12). We propose the terms "anastomosing wetlands" or "anastomosing palustrine system or environment" to designate these wetland ecosystems. The analogy with anastomosing river systems stems from the fact that they are composed of interconnected channels enclosing islandlike areas in one or multiple "channel belts" (e.g., Makaske 2001). However, the dissimilarity is that in an anastomosing river system, the island areas are saucer-like flood basins, whereas in an anastomosing palustrine system, they are mostly stable and subaerially exposed. In Persepolis' anastomosing wetlands, the island areas are mostly elongated along the main spring flow direction. Aerially, the wetlands are fan shaped, and their width increases from the resurgence point downstream (Figs. 5A, 5B). The slope gradient measured for 13 main springs and (or) spring deposits varies from 0.10 to 0.78 (Table 1 ). The orientation of the longitudinal axis of the wetlands may be almost straight (i.e., P3-P5), or curved (i.e., P6 and P8; Fig. 5), mainly controlled by the position and size of the adjacent alluvial fans compared with the position of the resurgence point of the springs, the latter being located mostly between the oldest alluvial fans (Fig. 5A). The total surface area of the visible anastomosing parts of 14 spring wetlands is approximately 5700 hectares $\left(5.7 \mathrm{~km}^{2}\right)$, giving a rough estimation of their minimum extension in the basin. However, this figure is certainly an underestimation because large parts of the anastomosing patterns have been erased as a result of artificial drainage, land reclamation, and intensive agriculture (e.g., Fig. 5: lower image).

Persepolis palustrine carbonates outcrop along natural gullies and also in the canals and wells dug for water exploitation and irrigation. One of the best exposed outcrops is found near the village of Shahijan (P10 in Fig. 2) in front of a cave named KMC by Rosenberg (1988), also called "Eshkaft-e Anjiri" in the local dialect $\left(30^{\circ} 4^{\prime} 52.47^{\prime \prime} \mathrm{N}, 52^{\circ} 31^{\prime} 45.95^{\prime \prime} \mathrm{E}\right.$; arrows in Fig. 7 and Figs. 8A, 8D). Three long canals have been dug down to $6 \mathrm{~m}$ deep in the eastwest and north-south directions (Fig. 7). Two lithological logs were drawn in these canals on the basis of visual facies characteristics in the field and then a more detailed examination in the laboratory (Figs. 7, 8). The sedimentary log S1 displays the vertical facies change beneath an anastomosing island, whereas the sedimentary log S2 depicts facies changes in an anastomosing channel location. The two sedimentary logs show a generally similar vertical facies succession but with a marked difference at the topmost sedimentary units. Both sedimentary sections are dominated by nodular calcareous muds with root traces and (or) vertical root cavities (Fig. 7). As shown in Fig. 7 (S1 and S2), the topmost sedimentary unit in S1 (S1-U1) is composed of a $\sim 1 \mathrm{~m}$ thick calcrete overlying a hardened carbonate mud with a network of horizontal and vertical root cavities (S1-U2). In contrast, the topmost unit in S2 (S2-U1) is a dark grey organic mud rich in plant remains and 
Fig. 7. Shahijan desiccated carbonate wetland (P1 in Fig. 1) in front of the Anjiri Cave (black arrow). Note the anastomosing pattern of the wetland with light-coloured areas representing subaerially exposed microtopographic highs with calcrete units (see section S1) and darkcoloured palustrine channels in which organic-rich calcareous mud and (or) peat are deposited (S2). Eye positions $8 \mathrm{a}$ and $8 \mathrm{~d}$ show the position and directions of pictures 8A and 8D, respectively, in Fig. 8; $\mathrm{g}$ and $\mathrm{h}$ show the position of two thin sections presented in Fig. 8. [Colour online.]
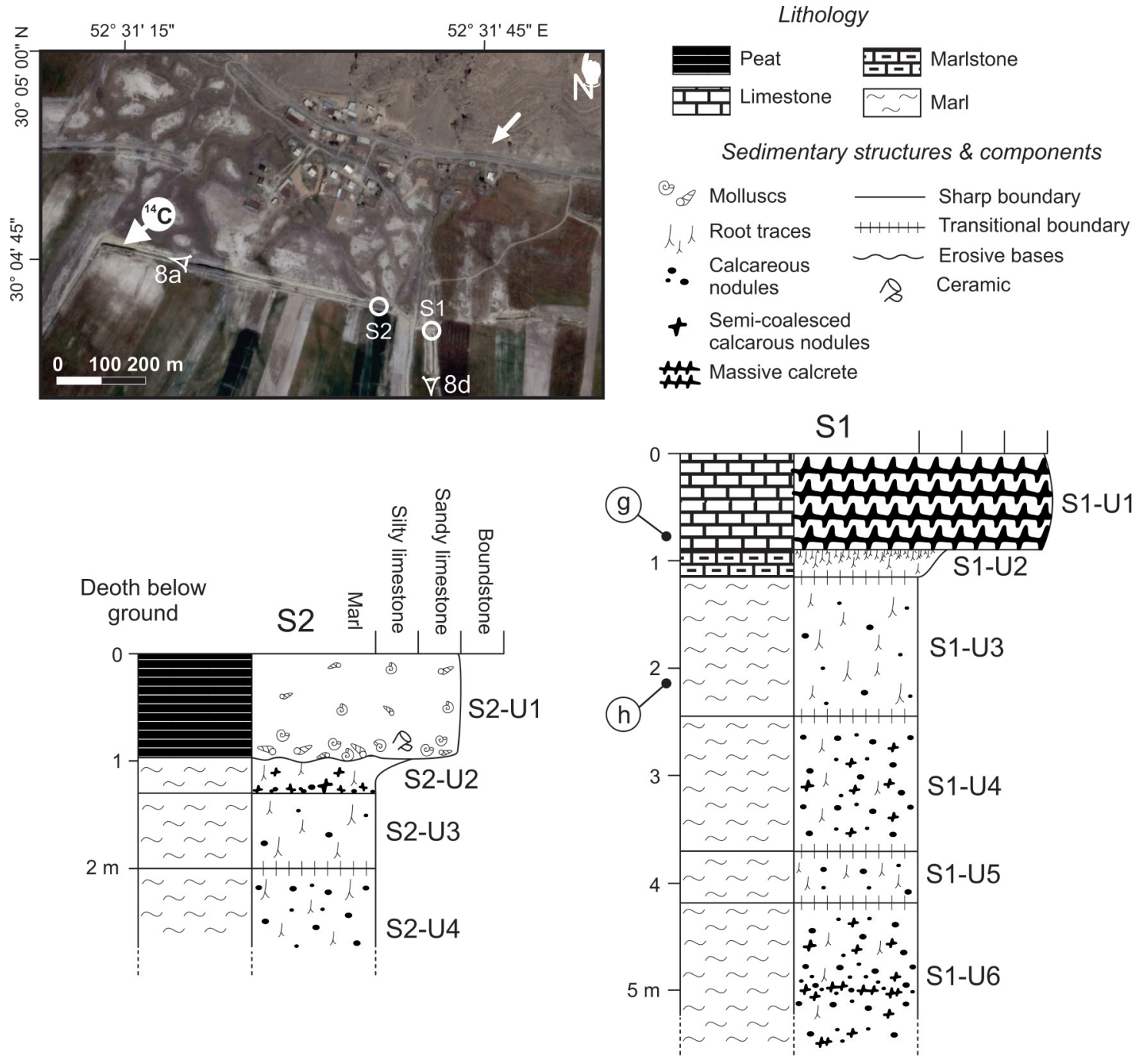

gastropods deposited on the lower marls with root traces and calcareous nodules (S2-U2). The boundary between these two latter units is erosive, indicating slowly flowing water in anastomosing palustrine channels.

Observation of several hundred metre long sections along canals provides insights into the spatial geometry of the wetland deposits (Fig. 8A). When walking along the east-west-oriented canal (Fig. 7), one notes several decimetric channel fills (Ch in Figs. 8A, 8B) cut into the grey marls, separated with areas of calcrete accumulation (Crt in Figs. 8A, 8D). These two sedimentary bodies, represented in sections S1 and S2 in Fig. 7, are superficial units overlying a very thick unit composed of carbonate muds and (or) marls (Mrl in Fig. 8B). This unit shows many characteristics typical of palustrine limestones, including calcareous nodules, root cavities or traces, and mottling with a generally prismatic massive structure. At about 2-3 $\mathrm{m}$ depth, there is an impressive $1 \mathrm{~m}$ thick, red-coloured, nodular, carbonate mud, which can be traced in all canals (Figs. 8A, 8E).

The radiocarbon samples from the western end of a canal in the Shahijan wetland (Figs. 7, 8A) both gave mid- to late Holocene ages (Table 2). The sample from the $210-212 \mathrm{~cm}$ depth provided an older age (5321-5580 cal BP) than the sample from $374-375 \mathrm{~cm}$

(4855-5039 cal BP), suggesting the contamination of the lower sample by roots and rootlets penetrating into older deposits from the overlying aquatic or terrestrial vegetation. Both ages, however, suggest that the exposed outcrops all formed during the Holocene.

\section{Discussion}

Karstic spring wetlands: modern analogues for ancient palustrine carbonate environments

To our knowledge, no karstic spring carbonate wetland has so far been proposed as a modern analogue for ancient palustrine environments. This is probably because of the scarcity of such wetland environments in regions of the world where such deposits have been studied intensively by sedimentologists (e.g., in southern France and the Iberian Peninsula (Freytet and Plaziat 1982; Alonso-Zarza 2003)). A number of sedimentological features observed in the studied carbonate deposits of the Persepolis Basin indicate that they are true palustrine carbonates, showing both deposition in low-energy waterlogged environments and later alteration by different pedogenetic processes. These deposits are 
Fig. 8. Palustrine carbonate facies of Shahijan. (A) Eastward view of a canal dug for water exploitation to the southwest of the KMC-Eshkaft-e Anjiri Cave (black arrow). Note the cross section of an anastomosing palustrine channel cut into the lower nodular and rooted marls (see sedimentary logs in Fig. 7). (B) Erosive contact between a palustrine channel deposit and an older marl deposit with isolated carbonate nodules and root traces. (C) A vertical carbonate nodule formed in a matrix of carbonate mud. (D) A northward view of another canal towards the KMC-Eshkaft-e Anjiri Cave (black arrow). (E) Facies succession in the same canal and under a zone of calcrete formation (section S1 in Fig. 7). (F) The base of the topmost calcrete layer (S1-U1 to S1-U2 boundary; Fig. 7). The lower layer is full of root cavities. (G and H) Photomicrographs of thin sections taken from the massive calcrete of unit S1-U1 and the nodular-rooted palustrine marl of unit S1-U3. Both show micritic nodules surrounded by curved cracks, the latter being partly filled with vadose microsparitic cement in the case of the calcretic unit showing the early diagenesis under meteoric conditions. Note the abundance of rounded and elongated voids left by fine-root systems typical of $\beta$-type calcrete microfabrics formed under biogenic processes. [Colour online.]
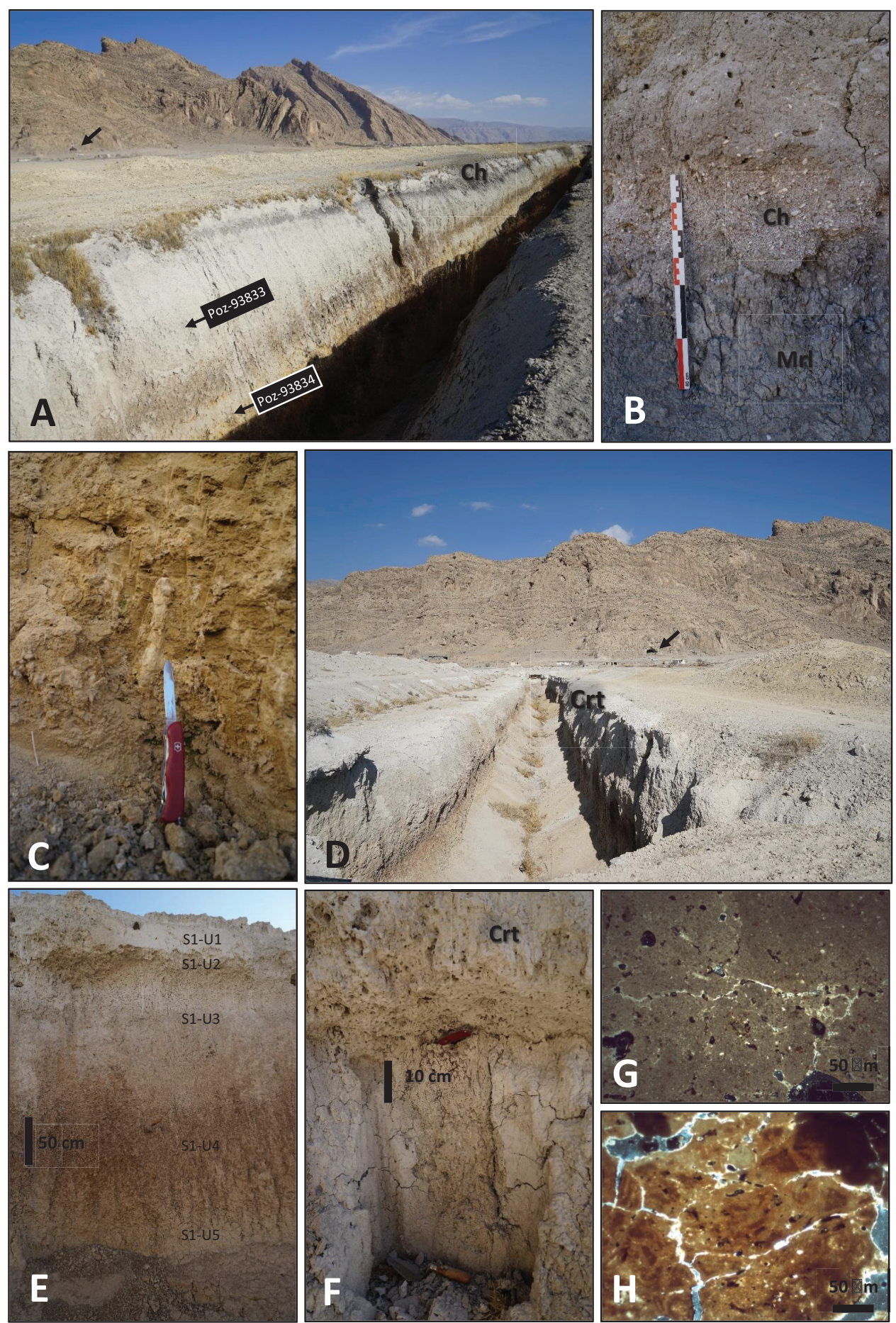
Table 2. Radiocarbon ages obtained for two samples taken from the western end of a canal in Shahijan wetland.

\begin{tabular}{llllll}
\hline Sample No. & Lab code & Depth $(\mathrm{cm})$ & $\begin{array}{l}{ }^{14} \mathrm{C} \text { age } \\
\text { (years BP) }\end{array}$ & $\begin{array}{l}\text { Age range } \\
(\text { cal BP })\end{array}$ & Material dated \\
\hline Shahijan 2_10-12 & Poz-93833 & $210-212$ & $4705 \pm 35$ & $5321-5580$ & Gyttja \\
Shahijan 3_74-76 & Poz-93834 & $374-376$ & $4370 \pm 35$ & $4855-5039$ & Extracted plant remains \\
\hline
\end{tabular}

Note: ${ }^{14} \mathrm{C}$ ages were calibrated using CALIB 6.1.1 based on the IntCal09 calibration dataset (Reimer et al. 2009). Calibrated ages are reported as age ranges within $2 \sigma$ ranges.

composed of mainly carbonate mud (micrite) and display many calcareous nodules, root cavities and traces, and mottling (Figs. 7, 8).

The lateral facies change from calcretic layers to organic muds and (or) peats may be interpreted in two different ways. It may show (i) a wetland complex in which the processes of sedimentation and soil formation have occurred simultaneously in relation to microtopographic variations; or (ii) an old, vast, continuous calcrete unit that was later eroded by spring water flow after the activation-reactivation of the springs in wetter climates. The first mechanism can be supported by the observation of a similar palustrine deposit at Zarand in northwestern central Iran (Djamali et al. 2006), where such lateral facies variations in lacustrine-palustrinefluvial deposits have also been reported. The main difference with the Persepolis spring wetlands is the presence of larger lacustrine units with evidence of high-energy environments including carbonate biogenic concretions (oncolites) in the Zarand complex. The palustrine channels described in Zarand are also of higher energy, attested to by the deposition of true conglomerates with pebbles made of carbonate concretions of both biogenic and pedogenic origin (Djamali 2002; Djamali et al. 2006). In addition, the Zarand lacustrine-palustrine deposits are located in the middle of a large alluvial plain and were formed because of high groundwater in a distal alluvial environment, similar to their equivalents in the Iberian Peninsula (Bustillo and Alonso-Zarza 2007; Huerta and Armenteros 2005). Furthermore, unlike the Zarand complex, some of the visited palustrine deposits in the Persepolis Basin have thick peat deposits. For instance, in the Rouzian wetland (Figs. 5B, 5C), the thickness of peat in the vicinity of the resurgence points exceeds $6 \mathrm{~m}$, as revealed by our coring surveys in 2012. This wetland, in addition to others (e.g., P9 and P12; Fig. 1), thus constitute palustrine complexes composed of peat, channel or pond organic mud, palustrine marls with pedogenic features, and calcretes. The anastomosing pattern of the Persepolis Basin palustrine deposits may also be interpreted as being channels that have incised the older calcretic soils, formed under more arid conditions during the last glacial period or the more seasonally marked conditions of the early Holocene (Djamali et al. 2010). The surface runoff could also have contributed to the erosion of the carbonate hardpans, especially when the wetlands are located between two adjacent alluvial fans. The absolute age determination of calcrete units or underlying sediments can help test each of the hypotheses mentioned earlier in the text. The two radiocarbon datings performed on the Shahijan wetland carbonates (Table 1; Fig. 8A) both suggest that the sedimentary units underlying both palustrine channel deposits and calcretes are of mid-Holocene age. The hypothesis that calcretes have formed simultaneously with adjacent organic muds is thus reinforced. A more detailed geochronological investigation is needed to understand the spatiotemporal relationships of different facies found in the Persepolis Basin.

In the basin fill deposits of the Marvdasht plain around the Kur River, the fine-grained sediments deposited in "backswamp" and "intermittent lake-swamp" paleoenvironments have been found in several soil-sediment profiles, especially in upper river floodplains (Kehl et al. 2009). Their deposition during the Late glacial and early Holocene has been linked to low evaporation rates and reduced infiltration caused by the high clay content of the sediment and the very gentle slope of the plain causing inefficient drainage. Their formation on the river floodplain is, however, unrelated to karstic springs, which are closer to the foot of the mountains. Indeed, in intermountain alluvial fills such as the Persepolis Basin, the spring palustrine deposits should be more intercalated between proximal alluvial rather than distal alluvial facies. The juxtaposition of distal parts of these deposits with central basin and (or) fluvial sediments is, however, quite plausible (e.g., Fig. 5A).

On the basis of our own field observations and a literature review (e.g., Kehl et al. 2005, 2009), it seems that in the Persepolis Basin, palustrine carbonates form in different sedimentary contexts including river floodplains, distal alluvial environments, and karstic spring wetlands. The boundary between these different environments is mostly transitional. For example, a quick look at the satellite images in Fig. 5A suggests that in the upstream, the hydrology of these wetlands is less dependent on the groundwater level compared with the downstream area, where there is a closer interplay between the wetland and regional water tables. The sedimentation in the lowermost parts of the anastomosing carbonate wetlands is also controlled by the regional water table. The best example of the interaction between spring wetland hydrology and regional groundwater is observed in the southern limits of the P12 wetland zone, in the west of the plain (Fig. 3). Here, towards the downstream part of this vast anastomosing carbonate wetland, the island-channel pattern gradually disappears and merges into a vast flat area formerly seasonally inundated (N.F. Miller, personal observation). Although a comparison of the sedimentary facies deposited in these contrasted environments is very interesting, the focus of the current study was on the palustrine deposits associated with karstic springs. Available radiocarbon datings suggest that the anastomosing palustrine system associated with the Shahijan wetland (P9) would be relatively young, dating back to the early to mid-Holocene. It may suggest that the activation or reactivation of karstic springs occurred during the Holocene, after increased precipitation sufficiently recharged the mountain karstic aquifers.

What is evident in our study is that the extension and thickness of palustrine carbonates formed in karstic springs are important enough to constitute significant sedimentary units in the intermountain basin fills of the Zagros Mountains. In this region, several geological features favour the formation of karstic spring carbonate wetlands: (i) the dominance of karstic limestone with overlying and underlying impermeable formations, (ii) the presence of anticlines with limbs formed of these formations, (iii) the fault systems cutting through the karstic aquifers, and (iv) a very gentle topography in the plain permitting very slow water flow and the formation of a waterlogged area. The continuous compressional tectonic regime governing the Zagros Mountains since the late Tertiary (Mouthereau et al. 2012) has maintained this geological configuration and the continuous deposition of karstic spring palustrine carbonates.

Karstic limestones cover $\sim 11 \%$ and $\sim 23 \%$ of the surface area of Iran and the Zagros Mountains, respectively (Raeisi and Kowsar 1997). In the southern Zagros, most of these karstic limestones outcrop in the form of northwest-southeast-oriented cylindrical anticlines (Figs. 1, 9), both of whose ends plunge down into the younger Quaternary alluvial sediments (Ashjari and Raeisi 2006). The basin-and-range physiography of the Zagros Mountains, espe- 
Fig. 9. Spatial distribution of carbonate outcrops in Southwest Asia (map after Williams and Fong (2010) based on Williams and Ford (2006)). Dark brown indicates continuous outcrops whereas pale brown shows areas with discontinuous outcrops. Note that the limestone formations dominate the Zagros Mountains and that the carbonate outcrops form mountain ranges separating alluvial basins in a basin-and-range topographical configuration. [Colour online.]

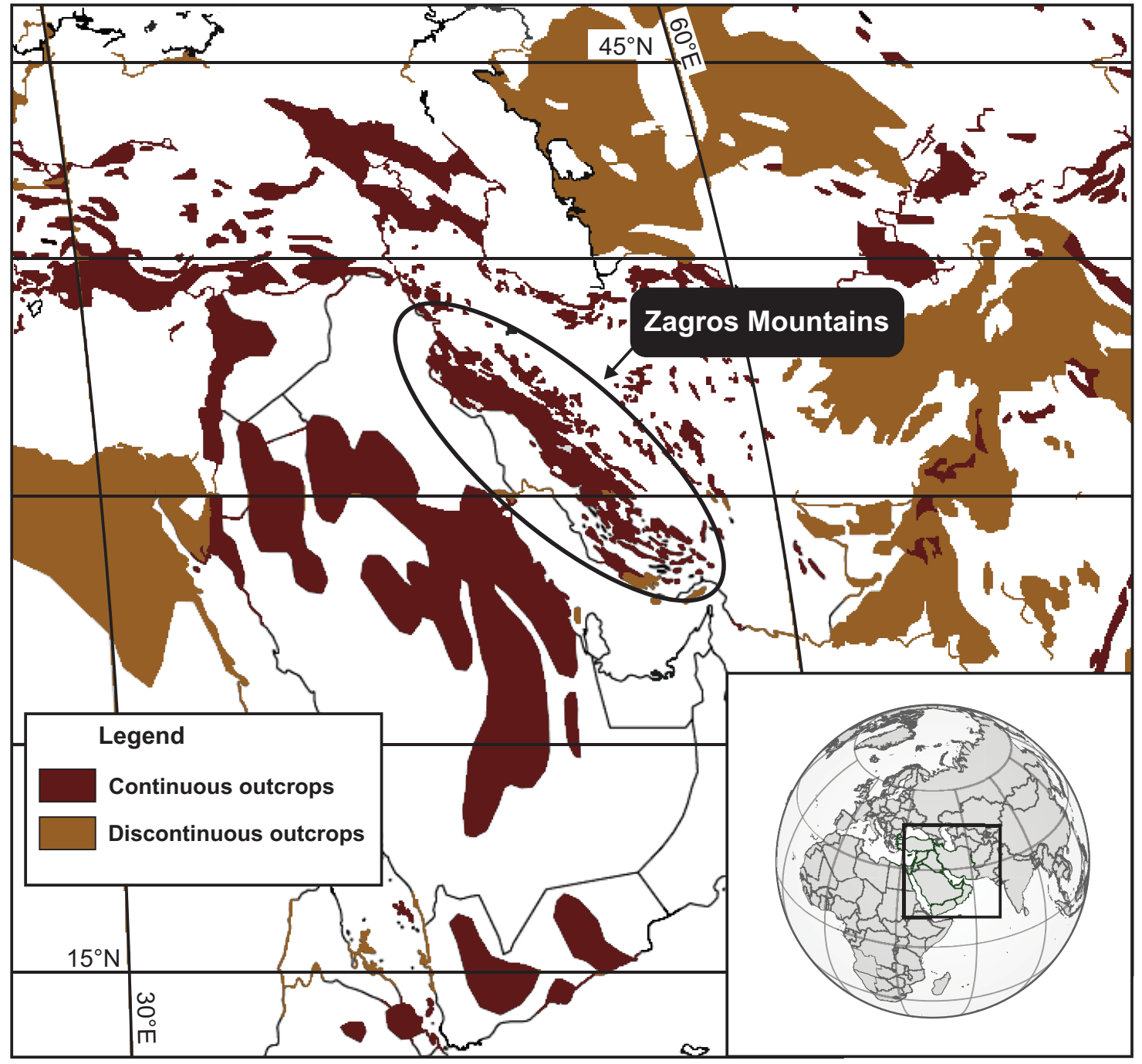

cially in the southern Zagros associated with the structure mentioned earlier in the text, provides geological conditions conducive to the formation of karstic carbonate wetlands. These wetlands are thus not limited to the Persepolis Basin but can be found in most of the intermountain basins of the southern and central Zagros. Indeed, some extensive carbonate wetlands and wetland deposits can also be found today in the subsiding basins of central (e.g., the Hashilan wetland: $34^{\circ} 34^{\prime} 56^{\prime \prime} \mathrm{N}, 46^{\circ} 53^{\prime} 27^{\prime \prime} \mathrm{E}$ ) and southern (e.g., $30^{\circ} 38^{\prime} 21^{\prime \prime} \mathrm{N}, 52^{\circ} 23^{\prime} 46^{\prime \prime} \mathrm{E}$ and $30^{\circ} 47^{\prime} 11^{\prime \prime} \mathrm{N}, 52^{\circ} 25^{\prime} 3^{\prime \prime} \mathrm{E}$ ) Zagros. The large extension of all these deposits suggests that they might constitute relatively thick geological units in the continental basin fill deposits of the Tertiary and Quaternary record of Zagros.

\section{Human and wetland interactions through time}

In the semiarid regions of the Middle East, including the southern Zagros, a freshwater resource such as a spring wetland can act as an oasis to attract human communities (Ames and Cordova 2014), which in turn exploit and modify the wetlands. The following examples show that human-wetland interactions have contributed to the development of civilizations in this region and that the traces of such interactions have been recorded in the wetland sedimentary archive.

\section{Shahijan desiccated wetland}

A pottery fragment attributed to the post-Achaemenid period (before 550 B.C.; F. Habibi, 2017, personal communication) was found in the basal part of a palustrine channel fill in Shahijan (S2-U1 in Fig. 7). This recently desiccated wetland is located a few metres from the KMC-Eshkaft-e Anjiri Cave (Figs. 7, 8A, 8C), which has revealed evidence of Upper Palaeolithic to Neolithic settlements (Rosenberg 1988; Shidrang et al. in press). The presence of freshwater wetland gastropod in the archaeological material of this cave suggests the use of peats and wetland vegetation by human communities living near the cave. Human communities have thus been interacting with this wetland since at least Upper Palaeolithic times.

\section{Tall-e Malyan, western Persepolis Basin}

The maps of Middle Palaeolithic to Upper Epi-Palaeolithic settlement patterns in the western part of the Persepolis Basin show that most of the settlements were close to water resources, including the Kur River and its tributaries and palustrine anastomosing wetlands (Rosenberg 1988; pages 571, 606, 639, 641). A number of the sites are located near the largest anastomosing palustrine environments of the western part of the plain (i.e., P10-P12; Fig. 1). 
Fig. 10. A selection of bird motifs redrawn from ceramic pieces of Tall-e Malyan (Anshan), suggesting the importance of waterfowl to the people living in the vicinity of the vast wetlands located in the western part of the Persepolis Basin (after Sumner 1999).

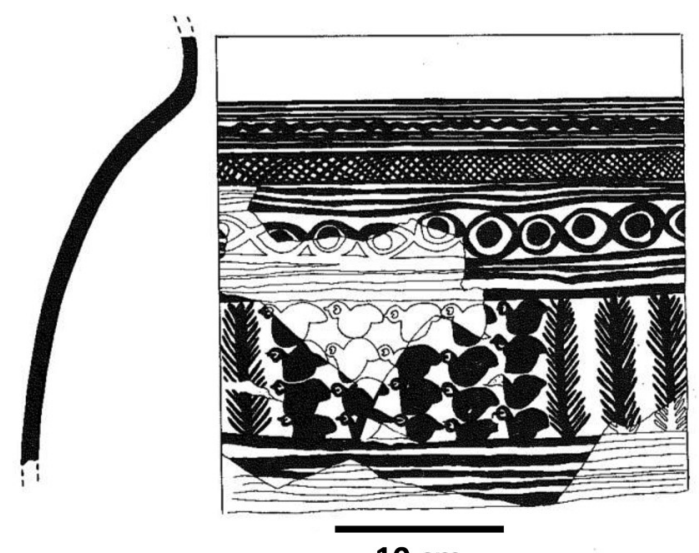

$10 \mathrm{~cm}$
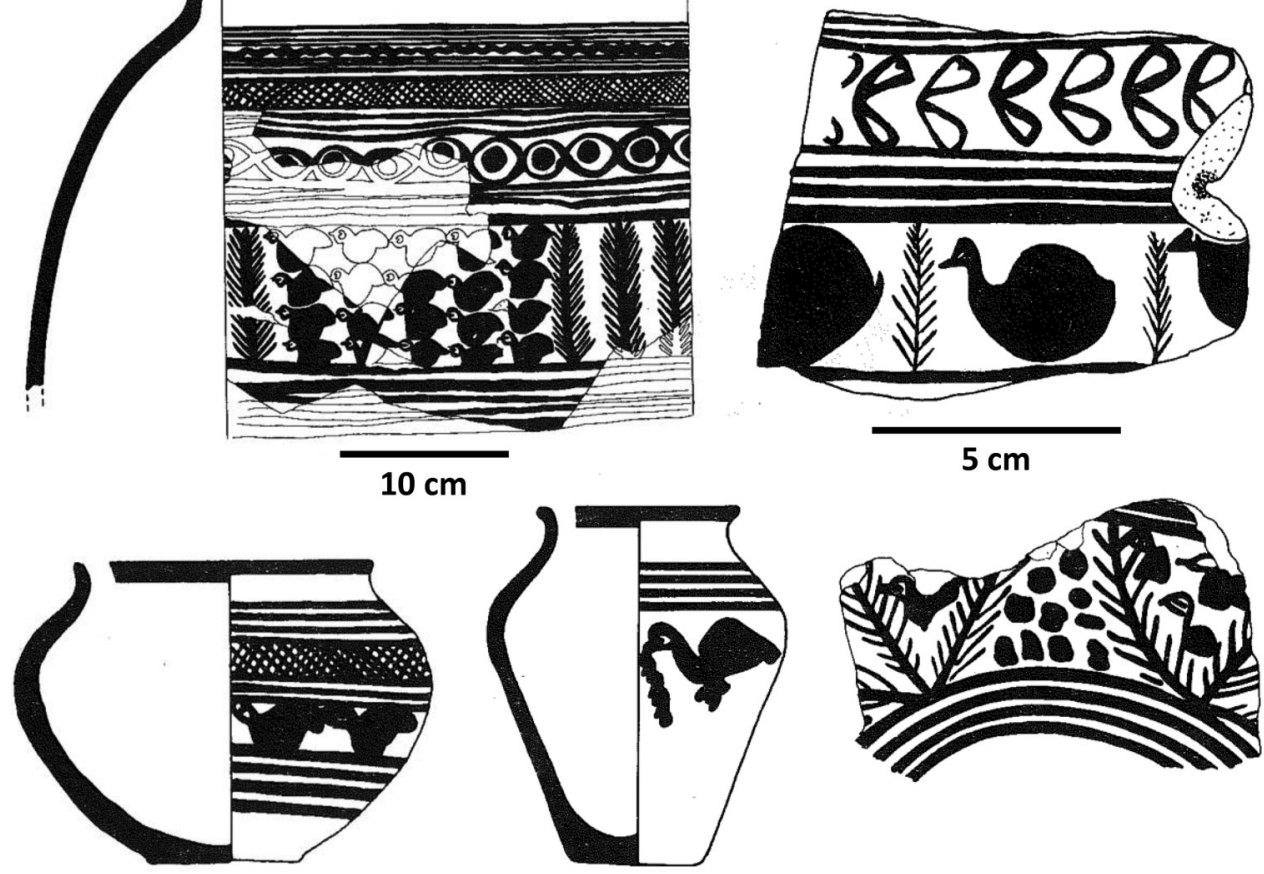

$5 \mathrm{~cm}$

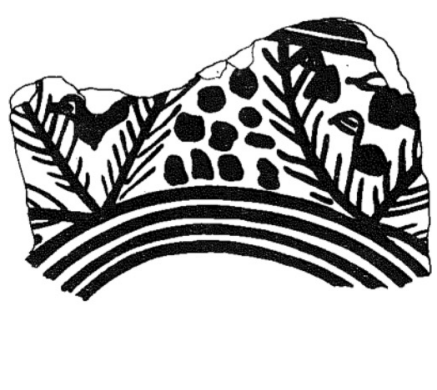

$5 \mathrm{~cm}$

Sumner's (1972) archaeological survey considered the distribution of settlements over time (ca. fifth to first millennium B.C.) in relation to water resources (marshes, springs, rivers, qanats, and wells). An examination of his survey maps highlights the fact that from the late Bronze Age (ca. 2200-1600 B.C.), known locally as the Kaftari period, people settled near the spring wetlands of P10-P12 (Fig. 2). There are also some sites close to the spring wetlands $\mathrm{P} 3$, P8, and P9. Given the likelihood that mobile pastoral communities occupied the region at least seasonally, these water sources could have been shared by herders and farmers. Miller's (1982) archaeobotanical study of Tall-i Malyan near the P10-P12 wetlands (Fig. 2) reports few seeds of any plants, either terrestrial or aquatic. Nevertheless, the proportion of seeds of wetlands and irrigated fields was higher in the Kaftari period (ca. 22001600 B.C.) than in the earlier Banesh period (ca. 3500-2700 B.C.), which suggests increased focus on wetland resources from the end of the third to the mid-second millennium B.C. Even though Malyan itself is not by a river, it was the economic and political centre of the Kur River Basin and was situated very close to the largest wetland system of the upper Persepolis Basin (P10-P12). People at Malyan could have acquired natural resources from this wetland and the irrigated landscapes around it. The archaeobotanical results (Miller 1982) were fully consistent with Sumner's observation that the Kaftari settlement was oriented toward water resources (rivers, springs, and wetlands). The archaeozoological evidence shows that waterfowl (e.g., ducks, geese, and cranes) constituted a very small fraction of the diet of people in Malyan during the Kaftari period (Zeder 1991). Interestingly, some of the motifs on Kaftari-period pottery are bird representations, many of which can be identified as waterfowl (Fig. 10) (Sumner 1999). All this evidence suggests that wetlands of the eastern Persepolis Basin were part of the economic landscape of the region of ancient Anshan, at least during the third and second millennia B.C.
Additional information on human-wetland interactions was collected during our recent field work in the Persepolis Basin. The natural profiles and man-made canals we examined revealed abundant archaeological material in the wetland sediments, attesting to the use of these wetlands by human societies in prehistoric as well as historical periods (see next sections).

\section{Band-e Gomban (Gomban water reservoir), northwest of Tashk playa lake}

In the extreme eastern part of the Persepolis Basin, and in the northwest margin of the playa lake of Tashk, well-preserved remnants of an impressive ancient water reservoir are still in place (Figs. 11A, 11B). This structure, called Band-e Gomban or Band-e Dokhtar-e Gomban, is an approximately $900 \mathrm{~m}$ long, $30 \mathrm{~m}$ wide, and $10 \mathrm{~m}$ high wall composed of limestone blocks and finer materials encircling a limestone hill. The ensemble impounded several freshwater springs, creating a huge water reservoir, which was possibly used to irrigate the agricultural lands of the area (Krinsley 1970; Kleiss 1992). Gomban spring waters have a high salt content $(5500 \mu \mathrm{S} / \mathrm{cm})$ originating from the salt diapirs, lakewater intrusion, high evapo-transpiration, and agricultural return flow (Raeisi and Nejati 2000). However, the salt content is low enough to be usable in irrigating the cultivated lands to the southwest of the springs. Today they are used intensively for irrigation of farmlands near the village of Gomban. The architectural elements used in the construction of Band-e Gomban suggest that it was probably built during the Achaemenid Empire and was then repaired and reused in later epochs (Kleiss 1992). Today, there are several spring resurgences all along the bottom of the ancient reservoir, with most of them associated with the formation of peat bogs. On the basis of our coring operation in September 2016, the easternmost of these peat bogs has a minimum of $4 \mathrm{~m}$ of wetland deposits composed of alternating peat and shallow pond or marsh muds. 
Fig. 11. Satellite images of two carbonate wetlands associated with springs P0 and P13, which display evidence for strong human intervention in the wetland ecosystem. (A) Gomban water reservoir dating to the Achaemenid period. (B) View of the reservoir from over the southern wall (see eye position in Fig. 11A). (C) The Qadamgah rock relief and its associated desiccated wetland. (D) A sediment profile along a drainage canal (see the eye position in Fig. 11C) representing a natural palustrine carbonate deposit (P0 in Figs. 1, 2) intercalated with a cultural layer comprising a mixture of ceramics (Achaemenid and post-Achaemenid), bone fragments, and decimetric angular rock fragments. A is from Google Earth, CNES/Airbus 2017 (date of image: 05 December 2016) and C is from Google Earth, CNES/Airbus 2017 (date of image: 13 October 2016). [Colour online.]
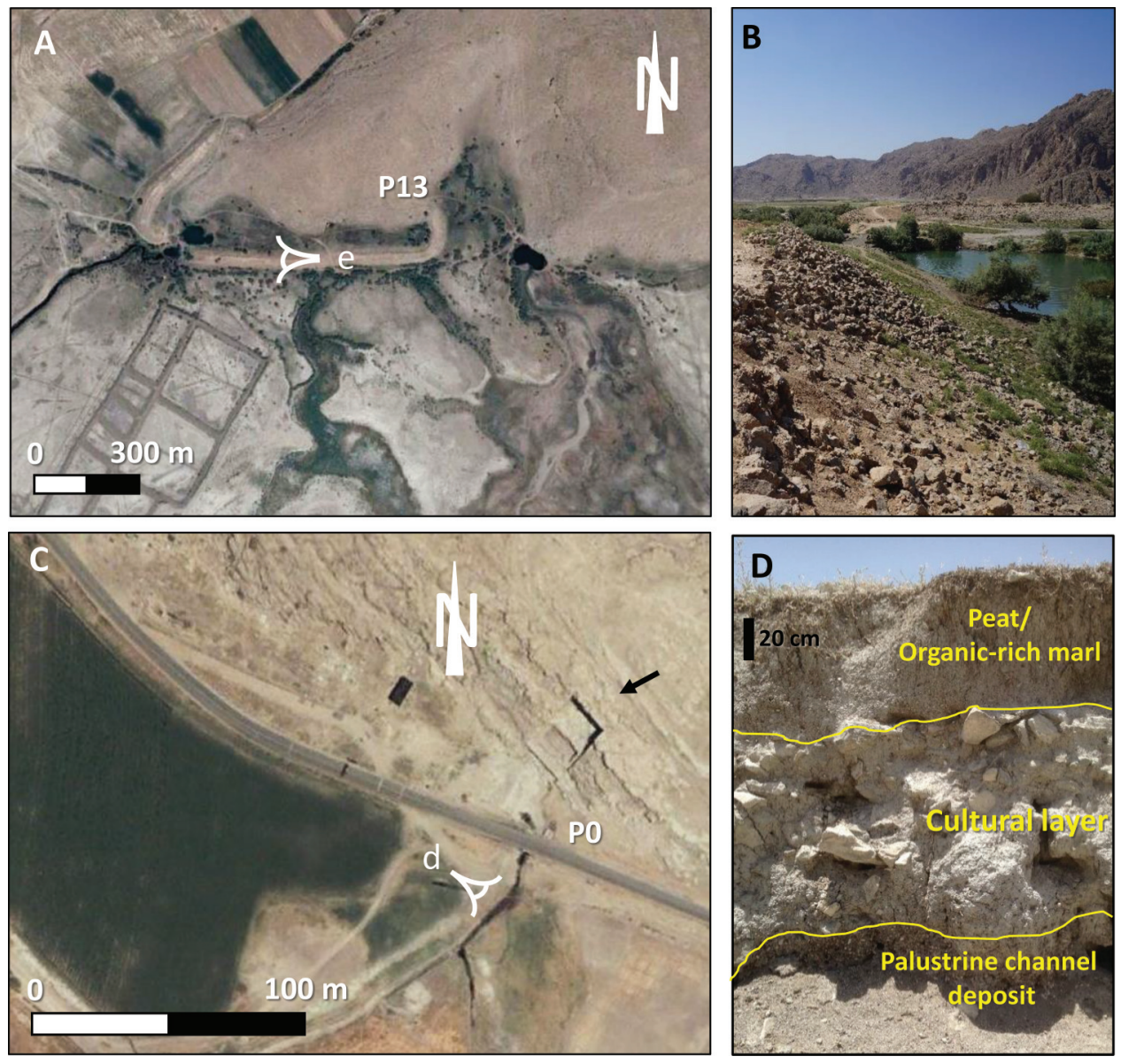

The construction of the reservoir has certainly transformed the spring wetland ecosystems into a small reservoir lake. The traces of such hydrological transformation would have been recorded in the subsurface sediments. Band-e Gomban is a unique example of historical water management, different from other contemporaneous works such as damming rivers, canaling springs, and digging wells and qanats. Instead, it impounds a karstic spring and elevates the water level into a desired level, necessitating the waterproofing and water tightening of the reservoir walls and substrate and the building of a complex outlet system (and possibly a spillway) to control the release of flows into the downstream area and canals to transfer the water into the farms and habitations. Band-e Gomban constitutes a unique archaeological archive that illustrates the architectural strategies used by ancient people to control water flows and to address problems related to dam leakage. Its bottom sediments should also display a unique sedimentary archive to reconstruct its hydrological evolution from a natural spring wetland into a man-made reservoir and then again into a seminatural spring wetland. For example, pollen analysis of sediments may potentially reveal the agricultural development related to the construction and use of the reservoir. Considering the historical importance of this unique construction, architectural preservation measures are needed urgently for this archaeological site.

\section{Qadamgah rock cutting, northeastern Persepolis Basin}

The best example of human-wetland interactions is observed in front of an impressive archaeological monument called "Qadamgah" (P0 in Fig. 1 and Fig. 11C). This monument is composed of a $600 \mathrm{~m}^{2}$ platform cut into the rock using techniques similar to those used to cut the royal tombs of the Achaemenid kings in Persepolis (Bessac 2007; Gondet 2011). A funerary use of this platform was proposed by Boucharlat $(1979,2003)$, but that purpose is not certain. The presence of a permanent spring is probably the main reason why Achaemenids or post-Achaemenids created this massive rockwork of still unknown use. Until recently, the Qadamgah spring was the place of an active freshwater spring, forming a large pond at the foot of the rock cutting. The water then flowed onto the plain, forming a vast anastomosing wetland. In an exposed man-made canal side, one can observe the alternation of natural wetland deposits and cultural materials. Figure 11D shows an image of this profile in which an anthropogenic layer composed of ceramics, rock fragments, and animal bones is intercalated between wetland deposits. Two ceramic finds in this layer suggest a post-Achaemenid, pre-Sasanian age (330 B.C.-224 A.D.). The thickness of the layer deposit and also the variety of archaeological materials in it suggest significant human activity during the Achaemenid period that persisted long after the period ended. 
In summary, the examples mentioned earlier in the text show that karstic spring wetlands provide not only a permanent source of fresh water for humans and animals but also for the development of a dense vegetation and irrigation and possibly an inspiration for ritual purposes as in Qadamgah. Spring water today contributes around $40 \%$ of Kur River water (Nadji 1997) and thus forms a major freshwater resource in the Persepolis Basin. The spatial distribution of these karstic springs should have influenced the prehistoric and historical settlement patterns in the Persepolis Basin, thereby playing a fundamental role in the development of civilizations in the southern Zagros Mountains.

\section{Conclusions}

Karstic springs emerging from carbonate outcrops surrounding alluvial plains can create carbonate wetlands in which palustrine carbonates are deposited. A basin-and-range topography dominated by carbonate formations located in subtropical latitudes with a semiarid climate seems to provide ideal environmental conditions for the formation of spring-fed palustrine carbonates. A Mediterranean continental climate characterized by a contrasted seasonality of precipitation and long dry seasons seems to be particularly conducive to the formation of such palustrine carbonates. These geoclimatic conditions have prevailed in Southwest Asia and the Mediterranean Basin since the closure of Neotethys and the Arabia-Eurasia continental collision. It is thus expected that spring-fed palustrine deposits have been a significant component of the geological record of these areas at least since the late Miocene.

The karstic spring carbonate wetlands in the Persepolis Basin have a particular spatial morphology that we call anastomosing wetland or anastomosing palustrine system or environment. Such ecosystems can provide a unique combination of fresh water and a rich biodiversity attractive to human communities. Indeed, in the spring carbonate wetlands of the Persepolis Basin, evidence of anthropogenic impacts is plentiful and dates from the late Pleistocene. Their existence favoured the settlement of the Persepolis Basin and spectacular development of the cultural landscape during prehistory and historical times. However, such long-term impacts have never caused total destruction of these ecosystems. Uncontrolled human exploitation of these freshwater resources has only occurred during the last decades. Measures to conserve these unique ecosystems, created by a few remaining karstic springs, should be taken urgently by Iran's environmental agencies. The conservation should also include the archaeological materials and structures associated with these ecosystems, which have yet to be explored for their geoarchaeological and paleoenvironmental potential.

\section{Acknowledgements}

This study was funded by the Franco-German ANR-DFG project entitled "PALEO-PERSEPOLIS" (ANR-14-CE35-0026-01). Special thanks go to Dr. Alireza Askari-Chaverdi, University of Shiraz, for his invaluable support of our project. We also thank Mr. Mousa Zarre for his support and availability during the field operations of 2012 and 2013 and Mr. Fazlollah Habibi for the identification of three pieces of ceramics. This study is dedicated to Pierre Freytet, Jean-Claude Plaziat (Université Paris-Sud, Orsay), and Ana-Maria Alonso-Zarza (Universidad Complutense Madrid) for their great contribution to introducing and developing the palustrine carbonate sedimentology.

\section{References}

Abdi, K. 2005. Malian, Encyclopaedia Iranica (online resource)

Alizadeh, A. 2006. The origins of state organizations in prehistoric Highland Fars, Southern Iran: excavations at Tall-e Bakun. Oriental Institute Publications, 128, Oriental Institute Publications, Chicago.

Alonso-Zarza, A.M. 2003. Palaeoenvironmental significance of palustrine carbonates and calcretes in the geological record. Earth-Science Reviews, 60: 261-298. doi:10.1016/S0012-8252(02)00106-X.
Alonso-Zarza, A.M., and Tanner, L.H. (Editors). 2006. Paleoenvironmental record and applications of calcretes and palustrine carbonates. Geological Society of America Special paper 416, Boulder, Colorado.

Alonso-Zarza, A.M., and Wright, V.P. 2009a. Palustrine carbonates. In Carbonates in Continental Settings: Facies, Environments, and Processes. Edited by A.M. Alonso-Zarza and L.H. Tanner. Developments in Sedimentology, Elsevier, Amsterdam, 61: 103-132.

Alonso-Zarza, A.M., and Wright, V.P. 2009b. Calcretes. In Carbonates in Continental Settings: Facies, Environments, and Processes. Edited by A.M. Alonso-Zarza and L.H. Tanner. Developments in Sedimentology, Elsevier, Amsterdam. 61: 177-224.

Ames, C.H., and Cordova, C. 2014. Middle and Late Pleistocene landscape evolution at the Druze Marsh site in northeast Jordan: implications for population continuity and hominin dispersal. Geoarchaeol: an International Journal, 30: 307-329. doi:10.1002/gea.21516.

Amiet, P. 1996. Elam. Archée Editeur, Auvers sur Oise.

Ashjari, J., and Raeisi, E. 2006a. Influences of anticlinal structure on regional flow, Zagros, Iran. Journal of Cave and Karst Studies, 68: 118-129.

Ashjari, J., and Raeisi, E. 2006b. Lithological control on water chemistry in karst aquifers of the Zagros Range, Iran. Cave and Karst Sciences, 33: 111-118.

Ashley, G.M., Maitima Mworia, J., Musya, A.M., Owens, R.B., Driese, S.G., Hover, V.C., et al. 2004. Sedimentation and recent history of a freshwater wetland in a semi-arid environment: Loboi Swamp, Kenya, East Africa. Sedimentology, 51: 1301-1321. doi:10.1111/j.1365-3091.2004.00671.x.

Barsi, J.A., Lee, K., Kvaran, G., Markham, B.L., and Pedelty, J.A. 2014. The Spectral Response of the Landsat-8 Operational Land Imager. Remote Sensing, 6: 10232-10251. doi:10.3390/rs61010232.

Barth, R. 1961. Nomads of South Persia, the Basseri Tribe of the Khamseh Confederay. Oslo University Press.

Beck, L. 1986. The Qashqai of Iran. New Haven, CT: Yale University Press.

Bessac, J.-C. 2007. Étude technique et interprétations du monument rupestre de Qadamgah (Fars). Iranica Antiqua 42: 185-206.

Boucharlat, R. 1979. Le monument rupestre de Qadamgah (Fars): Essai d'interprétation. Iranica Antiqua, 14: 153-166.

Boucharlat, R. 2003. The Persepolis area in the Achaemenid Period, some reconsiderations. In Yeki bud, Yeki nabud, Essays on the Archaeology of Iran in Honor of William, M. Sumner. Edited by W.M. Sumner, N.F. Miller, and K. Abdi. Cotsen Institute of Archaeology, UCLA, Los Angeles, Monograph, 48: 260-265.

Boucharlat, R., De Schacht, T., and Gondet, S. 2011. Surface reconnaissance in the Persepolis Plain 2005-2008. New data on the city organisation and landscape management. In Dariosh Studies II: Persepolis and its settlements: territorial system and ideology in the Achaemenid State. Edited by G.P. Basello and A.V. Rossi. Università degli Studi di Napoli "l’Orientale", Series Minor, LXXVIII: 249-260.

Bustillo, M.A., and Alonso-Zarza, A.M. 2007. Overlapping of pedogenesis and meteoric diagenesis in distal alluvial and shallow lacustrine deposits in the Madrid Miocene Basin, Spain. Sedimentary Geology, 198: 255-271. doi:10.1016/ j.sedgeo.2006.12.006

Daryaee, T., 2013. Sasanian Persia, the Rise and Fall of an Empire. I.B. Tauris \& Co Ltd., London.

De Schacht, T., De Dapper, M., Asadi, A., Ubelmann, Y., and Boucharlat, R. 2012. Geoarchaeological study of the Achaemenid dam of Sad-i Didegan (Fars, Iran). Géomorphologie: relief, processus, environnement, 1: 91-108.

Djamali, M. 2002. Depositional environment and palaeoecology of carbonate deposits of Zarand Plain, Saveh, W Zavyeh. Unpublished MSc thesis, Faculty of Science, University of Tehran (in Persian with English abstract).

Djamali, M., Esu, D., Gliozzi, E., Okhravi, R., and Soulié-Marsche, I. 2006. Palaeoenvironment of a lacustrine-palustrine carbonate complex: Zarand Basin, Saveh, Central Iran. Palaeogeography Palaeoclimatology Palaeoecology, 237: 315-334. doi:10.1016/j.palaeo.2005.12.001.

Djamali, M., de Beaulieu, J.-L., Shah-Hosseini, M., Andrieu-Ponel, V., Amini, A., Akhani, H., et al. 2008. A late Pleistocene long pollen record from Lake Urmia, NW Iran. Quaternary Research, 69: 413-420. doi:10.1016/j.yqres.2008.03.004.

Djamali, M., de Beaulieu, J.-L., Miller, N.F., Andrieu-Ponel, V., Lak, R., Sadeddin, M., et al. 2009. Vegetation history of the SE section of Zagros Mountains during the last five millennia; a pollen record from the Maharlou Lake, Fars Province, Iran. Vegetation History and Archaeobotany, 18: 123-136. doi:10.1007/s00334-0080178-2.

Djamali, M., Akhani, H., Andrieu-Ponel, V., Bracconnot, P., Brewer, S., de Beaulieu, J.-L., et al. 2010. Indian Summer Monsoon variations could have affected the early Holocene woodland expansion in the Near East. The Holocene 20, 813-820.

Djamali, M., Akhani, H., Khoshravesh, R., Andrieu-Ponel, V., Ponel, P., and Brewer, S. 2011. Application of the Global Bioclimatic Classification to Iran: implications for understanding the modern vegetation and biogeography. Ecologia Mediterranea, 37: 91-114.

Freytet, P. 1973. Petrography and paleo-environment of continental carbonate deposits with particular reference to the Upper Cretaceous and Lower Eocene of Languedoc (Southern France). Sedimentary Geology, 10: 25-60. doi:10.1016/ 0037-0738(73)90009-2.

Freytet, P. 1984. Les sédiments lacustres carbonatés et leurs transformations par émersions et pédogenèse. Importance de leur identification pour les reconsti- 
tutions paléogéographiques. Bulletin du Centre de Recherche et ExplorationProduction, Elf-Aquitaine, 8: 223-247.

Freytet, P., and Plaziat, J.-C. 1982. Continental carbonate sedimentation and pedogenesis. Late Cretaceous and Early Tertiary of Southern France. Contribributions to Sedimentary Geology 12, Schweizerbartsche Verlagsbuchhandlung, Stuttgart, Germany.

Freytet, P., and Verrecchia, E.P. 2002. Lacustrine and palustrine carbonate petrography: an overview. Journal of Paleolimnology, 27: 221-237. doi:10.1023/ A:1014263722766.

Gondet, S. 2011. Occupation de la plaine de Persépolis au Ier millénnaire av. J.-C. (Fars central, Iran). PhD thesis, Université Lumière Lyon 2, Lyon.

Hosseini Fasae, H. (Editor) 1984. Farsnama Naseri. Amirkabir Publication, Tehran, Iran.

Huerta, P., and Armenteros, I. 2005. Calcrete and palustrine assemblages on a distal alluvialfloodplain: a response to local subsidence (Miocene of the Duero Basin, Spain). Sedimentary Geology, 177: 235-270.

Ibn Balkhi, A.Z.A. 1921. Fārs-nāma of Ibn Balkhi, 1099 AD. Cambridge University Press, Cambridge.

IOOC. 1969. 1:1,000,000 Geological Map of South-West Iran, Geological and Exploration Division, IOCC.

Jones, M.D., Djamali, M., Holmes, J., Weeks, L., Leng, M.J., Lashkari, A., et al. 2015. Human impact on the hydroenvironment of Lake Parishan, SW Iran, through the late Holocene. The Holocene, 25: 1651-1661. doi:10.1177| 0959683615594242.

Kehl, M., Frechen, M., and Skowroneck, A. 2005. Paleosols derived from loess and loess-like sediments in the Basin of Persepolis, Southern Iran. Quaternary International, 140/141: 135-149. doi:10.1016/j.quaint.2005.05.007.

Kehl, M., Frechen, M., and Skowroneck, A. 2009. Nature and age of Late Quaternary basin fill deposits in the Basin of Persepolis/Southern Iran. Quaternary International, 196: 57-70. doi:10.1016/j.quaint.2008.06.007.

Khalaf, F.I., and Gaber, A.S. 2008. Occurrence of cyclic palustrine and calcrete deposits within the lower pliocene Hagul formation, east Cairo district, Egypt. Journal of African Earth Sciences, 51: 298-312. doi:10.1016/j.jafrearsci. 2008.01.009.

Kleiss, W. 1992. Dammbauten aus achaemenidischer und aus sasanidischer Zeit in der Provinz Fars. Archaeologische Mitteilungen aus Iran (N.S.), 25: 131-145.

Komijani, S., Mashkour, M., Mohaseb, A., Fathi, H., and Azizi Kharanghi, H. In press. The archaeozoology of the Pre-Pottery and Pottery Neolithic site of Qasr-e Ahmad (Iran). Archaeozoology of the Near East, 12. Proceedings of the Groningen. 2015 ASWA conference. Groningen Archaeological Series. Groningen.

Kortum, G. 1976. Die Marvdasht-Ebene in Fars: Grundlagen und Entwicklung einer alten iranischen Bewasserungslandschaft, Kieler Geographische Schriften, Band 44. Elbstverlag des Geographischen Instituts der Universität Kiel, Kiel.

Krinsley, D. 1970. Geomorphological and paleoclimatological study of the playas of Iran. Geological Survey, United States Department of Interior, Washington.

Makaske, B. 2001. Anastomosing rivers: a review if their classification, origin and sedimentary products. Earth Science Reviews, 53: 149-196. doi:10.1016/S00128252(00)00038-6.

Mashkour, M., Mohaseb, A., and Debue, K. 2006. Chapter 10. Towards a specialized subsistence economy in the Marvdasht Plain: Preliminary zooarchaeological analysis of Mushki. Jari, B., Jari, A., Bakun, A. and B. In The Origins of State Organizations in Prehistoric Highland Fars, Excavations at Tall-e Bakun. Edited by A. Alizadeh, with contributions of M. Kimiaie, M. Mashkour, and N.F. Miller. Oriental Institut Publications, Chicago, Illinois, 128: 101-105.

Miller, N.F. 1982. Economy and Environment of Malyan, a Third Millennium B.C. Urban Center in Southern Iran. Ph.D. dissertation (Anthropology), University of Michigan, Ann Arbor.

Mousavi, A. 2012. Persepolis: Discovery and Afterlife of a World Wonder. Walter de Gruyter. 277 p.

Mouthereau, F., Lacombe, O., and Vergés, J. 2012. Building the Zagros collisional orogen: timing, strain distribution and the dynamics of Arabia/Eurasia plate convergence. Tectonophysics, 532-535: 27-60. doi:10.1016/j.tecto.2012.01.022.

Nadji, M. 1997. Rerouting of the Kor River from the Zagros region into the Persian Gulf-a proposed solution to the problem of salinization in the Persepolis Basin, Iran. Zeitschrift Angewande Geologie, 43: 171-178.

Platt, N.H., and Wright, V.P. 1992. Palustrine carbonates at the Florida Everglades: towards an exposure index for the freshwater environment. Journal of Sedimentary Petrology, 62: 1058-1071.

Plaziat, J.-C. 1984. Le biotope palustre: méthode d'identification paléoécologique. Geobios. Mémoire Spécial, 8: 313-320.

Plaziat, J.-C., and Freytet, P. 1978. Le pseudo-microkarst pédogénique: un aspect particulier des paléo-pédogenèse développées sur les dépôts calcaires la- custres dans le tertiaire du Languedoc. Comptes Rendus de l'Académie des sciences de Paris, 286: 1661-1664.

Pollock, S., Bernbeck, R., Abdi, A. (Editors). 2003. Social Life in a Neolithic Village. Excavations at Tol-e-Baši, Iran. Archäologie Mitteilungen in Iran und Turan, 10: $215-229$.

Potts, D.T. 1999. The Archaeology of Elam. Formation and Transformation of an Ancient Iranian State. Cambridge.

Raeisi, E., and Kowsar, N. 1997. Development of Shapour Cave, Southern Iran. Cave and Karst Science, 24: 27-34.

Raeisi, E., and Nejati, M.H. 2000. Study of the sources of salinity in the Gomban karst spring, southern Iran. Carbonates and Evaporites, 15: 115-120. doi:10. 1007/BF03175818.

Reimer, P.J., Baillie, M.G.L., Bard, E., Bayliss, A., Beck, J.W., Blackwell, P.G., et al. 2009. IntCal09 and Marine09 radiocarbon age calibration curves, 0-50000 years cal BP. Radiocarbon, 51: 1111-1150. doi:10.1017/S0033822200034202.

Reiner, E. 1973. The Location of Anshan. Revue d'Assyriologie, 67: 57-62.

Rigot, J.-B. 2010. Dynamique de la rivière Poulvar et morphogenèse de la plaine de Tang-i Bulaghi (Fars, Iran) à l'Holocène. Premiers résultats. Géomorphologie, processus, environnement, 1: 57-72.

Rosenberg, M. 1985. Report on the 1978 Sondage at Eshkaft-e Gavi. Iran, 23: 51-62. doi:10.2307/4299753.

Rosenberg, M. 1988. Paleolithic settlement patterns in the Marv Dasht, Fars Province, Iran, Ph.D. dissertation, University of Pennsylvania, University Microfilms International.

Rosenberg, M. 2003. The Epipaleolithic in the Marvdasht. In Yeki bud, yeki nabud: essays on the archaeology of Iran in honor of William M. Sumner. Edited by N.F. Miller and K. Abdi. University of California Institute of Archaeology. Cotsen Institute of Archaeology, Los Angeles, Monograph, 48: 98-108.

Scott, J.E., and Marean, C.W. 2009. Paleolithic hominin remains from Eshkaft-e Gavi (southern Zagros Mountains, Iran): description, affinities, and evidence for butchery. Journal of Human Evolution, 57: 248-259. doi:10.1016/j.jhevol. 2009.05.012.

Sheikhi Seno, S., Mashkour, M., and Sardari, A. 2011. Subsistence Economy of the Lapui settlement of Tepe Mehr Ali Fars on the basis of the archaeozoological analysis. Journal of Iranian Archaeology, 2: 39-60.

Shidrang, S., Mashkour, M., and Biglari, F. In press. The late Pleistocene human occupation of the Marvdasht plain and adjacent areas: evidence from. 2000s surveys. In The Paleolithic of Iran. Edition National Museum Iran.

Stevens, L.R., Wright, H.E., Jr., and Ito, E. 2001. Proposed changes in seasonality of climate during the Late-glacial and Holocene at Lake Zeribar, Iran. The Holocene, 11: 747-756. doi:10.1191/09596830195762.

Sumner, W.M. 1972. Cultural Development in the Kur River Basin. An Archaeological Analysis. Ph.D. dissertation (Anthropology), University of Pennsylvania, Philadelphia.

Sumner, W.M. 1999. The birds of Anshan. In Essays on Iranian art and archaeology. Edited by A. Alizadeh, Y. Majidzadeh, and S.M. Shahmirzadi. Iran University Press, Tehran.

Sumner, W.M. 2003. Early urban life in the land of Anshan: excavations at Tal-e Malyan in the Highlands of Iran. Malyan excavation reports 3. University Museum of Archaeology and Anthropology, University of Pennsylvania, Philadelphia.

Tanner, L.H. 2010. Continental carbonates as indicator of paleoclimate. In Carbonates in Continental Settings: Geochemistry, Diagenesis and Applications. Edited by A.M. Alonso-Zarza and T.H. Tanner. Developments in Sedimentology, Elsevier, Amsterdam, 62: 179-214.

Tsuneki, A., and Nishida, M. 2007. Stone Tools from Arsanjan area. Fars Province, Iran. Tsukuba University.

Vallat, F. 1980. Suse et l'Élam, Recherche sur les grandes civilisations, mémoire 1, Paris.

Wasylikowa, K., van Zeist, W., Wright, Jr., H.E., Stevens, L., Witkowski, A., Walanus, A., et al. 2008. The Lake Zeribar palaeoecology: a synthesis. In The palaeoecology of Lake Zeribar and surrounding areas, Western Iran, during the last 48,000 years. Edited by K. Wasylikowa and A. Witkowski. Diatom Monographs 8, A.R.G. Gantner Verlag K.G., Ruggel, pp. 303-321.

Williams, P.W., and Fong, Y.T. 2010. World Carbonate Outcrop Areas, v.3.0. SGGES, University of Auckland, New Zealand.

Williams, P.W., and Ford, D.C. 2006. Global distribution of carbonate rocks. Zeitschrift für Geomorphologie, 147: 1-2.

Wright, V.P., and Platt, N.H. 1995. Seasonal wetland carbonate sequences and dynamic catenas: a re-appraisal of palustrine carbonates. Sedimentary Geology, 99: 65-71. doi:10.1016/0037-0738(95)00080-R.

Yousefi, T., Khademi, E., and Andalibi, A. 2001. 1:100,000 Geological map of Arsanjan. Geological Survey and Mineral Exploration of Iran, Tehran, Iran.

Zeder, M.A., 1991. Feeding cities: Specialized animal economy in the ancient Near East. Smithsonian Institution Press, Washington DC. 